\title{
Geology, petrology and geochronology (Pb-Pb) of the Serra da Bocaina Formation: evidence of an Orosirian Amoguijá Magmatic Arc in the Rio Apa Terrane, south of the Amazonian Craton
}

\author{
Geologia, petrologia e geocronologia $(\mathrm{Pb}-\mathrm{Pb})$ da Formação Serra da \\ Bocaina: evidências de um Arco Magmático Orosiriano no Terreno \\ Rio Apa, sul do Cráton Amazônico
}

\author{
Ana Flávia Nunes Brittes ${ }^{1,2,3 *}$, Maria Zélia Aguiar de Sousa ${ }^{1,2,3,4}$, Amarildo Salina \\ Ruiz $^{1,2,3,5}$, Maria Elisa Fróes Batata ${ }^{2}$, Jean-Michel Lafon ${ }^{3,6}$, Dalila Pexe Plens $\mathbf{s}^{1,2,3}$
}

\begin{abstract}
This work presents the results of the geological mapping and the petrological characterization of the Serra da Bocaina Formation belonging to the Amoguijá Magmatic Arc of the Rio Apa Terrain. In the Bocaina hills, the Serra da Bocaina Formation consists of intermediately to predominately acidic volcanic rocks, classified as andesites and rhyolites and subdivided into five petrographic facies, which include four volcanoclastics and one effusive. In the studied rocks, tectonic structures are generated in two compressive ductile to ductile-brittle deformational phases. The first phase, which is more intense, presents along the entire studied area and is responsible for the Santa Rosa Shear Belt, whereas the second phase is more localized. The geochemical study indicates a calc-alkaline magmatism of medium to high $\mathrm{K}$, peraluminous, and generated in a volcanic arc environment. These volcanic rocks formed in an explosive environment related to the Amoguijá Magmatic Arc, as indicated by their $\mathrm{Pb}-\mathrm{Pb}$ zircon age of $1877.3 \pm 3.9 \mathrm{Ma}$.
\end{abstract}

KEYWORDS: Amazonian Craton; Serra da Bocaina Formation; geochemistry; geochronology.
RESUMO: Neste trabalho apresentam-se os resultados do mapeamento geológico e caracterização petrológica da Formação Serra da Bocaina, pertencente ao Arco Magmático Amoguijá do Terreno Rio Apa, sul do Cráton Amazônico. A Formação Serra da Bocaina, na serra da homônima, consiste de rochas vulcânicas paleoproterozoicas de composiçäo intermediária a predominantemente ácida, classificadas como andesito e riolitos, subdivididas em cinco fácies petrográficas sendo quatro piroclásticas e uma efusiva, que mantêm contato tectônico, a leste, com o Granito Carandá. Nas rochas estudadas estruturas tectônicas são formadas em duas fases deformacionais compressivas de natureza dúctil e dúctil-rúptil, respectivamente. A primeira fase, mais intensa, é observada ao longo de toda a área estudada e é responsável pela Zona de Cisalhamento Santa Rosa enquanto a segunda fase é mais discreta e localizada. O tratamento geoquímico indica que essas rochas foram geradas num ambiente de arco-vulcânico a partir de um magmatismo calcioalcalino de médio a alto-K, peraluminoso. Estas rochas retratam um evento magmático extrusivo, de natureza explosiva, relacionado à evolucão do Arco Magmático Amoguijá, conforme resultado Pb-Pb em zircāo de $1877,3 \pm 3,9$ Ma., interpretada como idade de cristalização destas rochas.

PALAVRAS-CHAVE: Cráton Amazônico; Formaçāo Serra da Bocaina; geoquímica; geocronologia.

\footnotetext{
${ }^{1}$ Graduate Program in Geosciences, Instituto de Ciências Exatas e da Terra - ICET, Universidade Federal de Mato Grosso - UFMT, Cuiabá (MT), Brazil. E-mail: afbrittes@gmail.com

${ }^{2}$ Research Group in Crustal Evolution and Tectonics - Guaporé, Mineral Resources Department, ICET, UFMT, Cuiabá (MT), Brazil.

${ }^{3}$ National Institute of Sciences and Geoscience Technology of the Amazon (Instituto Nacional de Ciência e Tecnologia de Geociências da Amazônia - GEOCIAM), Geosciences Institute of Universidade Federal do Pará - UFPA, Belém (PA), Brazil.

${ }^{4}$ Mineral Resources Department, ICET, UFMT, Cuiabá (MT), Brazil. E-mail: prof.mzaguiar@gmail.com

${ }^{5}$ General Geology Department, ICET, UFMT, Cuiabá (MT), Brazil. E-mail: asruiz@gmail.com

${ }^{6}$ Isotope Geology Laboratory (Pará-Iso), Geosciences Institute of UFPA, Belém (PA), Brazil. E-mail:lafonjm@ @ufpa.br

*Corresponding author

Manuscrito ID 26668. Recebido em: 22/04/2012. Aprovado em: 25/09/2012
} 


\section{INTRODUCTION}

The Rio Apa Terrane comprises a Paleoproterozoic crustal segment exposed in a restricted area of the southwestern part of the state of Mato Grosso do Sul (MS) on the Brazilian border with Paraguay. It is bounded on its eastern side by pelitic-carbonate rocks of the Corumbá Group and covered on its western side by Cenozoic sediments of the Pantanal Basin.

The Amoguijá Magmatic Arc is composed of plutonic rocks from the Alumiador Intrusive Suite and by effusive and pyroclastic rocks from the Serra da Bocaina Formation (Formação Serra da Bocaina - FSB). U-Pb SHRIMP zircon data indicate an age of 1,794 Ma for the volcanic rocks and 1,867 $\mathrm{Ma}$ for the intrusive equivalents of this arc (Lacerda Filho et al. 2006).

The FSB is located near the municipality of Porto Murtinho in MS and contains important geological records of the tectonic and magmatic evolution of the Orosirian period. This study aimed to contribute to the understanding of the magmatic event responsible for generating the effusive and pyroclastic units of the FSB by utilizing geological mapping — on a scale of 1:50,000 — in addition to petrographic, geochemical and geochronological studies ( $\mathrm{Pb}-\mathrm{Pb}$ zircon).

\section{REGIONAL GEOLOGICAL CONTEXT}

The study area is located in the Rio Apa Terrane, south of the Amazonian Craton, which is a region whose origin has been the subject of debate, particularly concerning whether it is a part of the craton. In early conceptions of the Amazonian Craton (Almeida 1964; Hasui \& Almeida 1970; Suszczynski 1970; Amaral 1974, 1984), the Rio Apa Terrane is included as part of it. However, based on the models suggested by Cordani et al. (1979), Litherland \& Bloomfield (1981) and Litherland et al. (1986), the Rio Apa Terrane was eliminated from Amazonian Craton reconstructions, and the Tucavaca range was established as the southern boundary of the craton.

The physical unconformity between the Rio Apa Terrane and the large geotectonic entities of the South American Platform has sparked a debate about the tectonic correlation of the terrane. Whereas Almeida (1964, 1978), Amaral (1974), Ruiz et al. (2005), Lacerda Filho et al. (2006) and Cordani et al. (2010) place it in the Amazonian Craton, Ramos (2008) emphasizes its connection with the Pampia Terrane (Argentina), and Ramos and Vujovich (1993) argue that it is an extension of the Rio de La Plata Craton.

Ruiz (2005) bases his position that the Rio Apa Terrane is part of the Amazonian Craton (Fig. 1) on the following arguments: (i) the Cuiabá Group and other units from the Paraguay Belt exhibit physical conformity from Nova Xavantina (Mato Grosso state - MT) to Serra da Bodoquena (MS) and Paraguay; (ii) the Tucavaca Range deformation is characterized by a weak compression giving rise to large waves and discreet thrusts; (iii) the units of the Tucavaca Belt (Boqui, Tucavaca and Murciélago Groups) are stratigraphically correlated with the units of the Paraguay Belt in southwestern Brazil (Jacadigo and Alto Paraguay Groups); and (iv) throughout its extension, the Amazonian Craton behaved like a passive continental margin during the deposition portion of the Paraguay Belt.

Based on its geological, geochemical and geochronological characteristics, Lacerda Filho et al. (2006) presented a tectonic partitioning of the Rio Apa Terrane and subdivided it into the following three distinct tectonic environments: the Oceanic Crust Remnant (2.2 to $1.95 \mathrm{Ga}$ ), the Rio Apa Magmatic Arc (1.95 to $1.87 \mathrm{Ga}$ ) and the Amoguijá Magmatic Arc (1.87 to 1.75 Ga).

The Amoguijá Magmatic Arc consists of a plutono-volcanic complex of an acidic nature, composed of the Alumiador Intrusive Suite and the Serra da Bocaina volcanics (Fig. 2). We will use the name FSB (Brittes \& Plens 2010, Brittes et al. 2010, 2011a, b and c) to designate the effusive and pyroclastic rocks exposed on the Bocaina and São Francisco mountain ranges, which is consistent with the parameters established by the Brazilian code of stratigraphic nomenclature (Petri et al. 1986).

Lacerda Filho et al. (2006), Godoy et al. (2010) and Cordani et al. (2010) describe the Alumiador Intrusive Suite as an elongated batholith of N-S direction that presents predominantly syeno- to monzogranitic composition and that consists of isotropic to slightly anisotropic leucocratic rocks whose color ranges from gray to pink.

According to Araújo et al. (1982), Godoi et al. (2001), Lacerda Filho et al. (2006) and Godoy et al. (2010), the FSB consists of rhyolites, rhyodacites and dacites with interbedded pyroclastic rocks, volcanic breccias and lava horizons with no evidence of flow. In addition to the volcanic rocks, the unit also contains subvolcanic bodies, represented by microgranites and micromonzonites (Lacerda Filho et al. 2006).

The FSB is divided into the following three main segments: the northern segment, called Serra de São Francisco; the central segment, which is of the greatest significance and called Serra da Bocaina; and, the southern segment (which is also called Serra da Bocaína) that approaches the Alumiador Intrusive Suite occurrences at Serra da Esperança near the Apa River.

U-Pb SHRIMP zircon dating (Tab. 1) obtained from a sample of porphyritic monzogranite from the Alumiador 


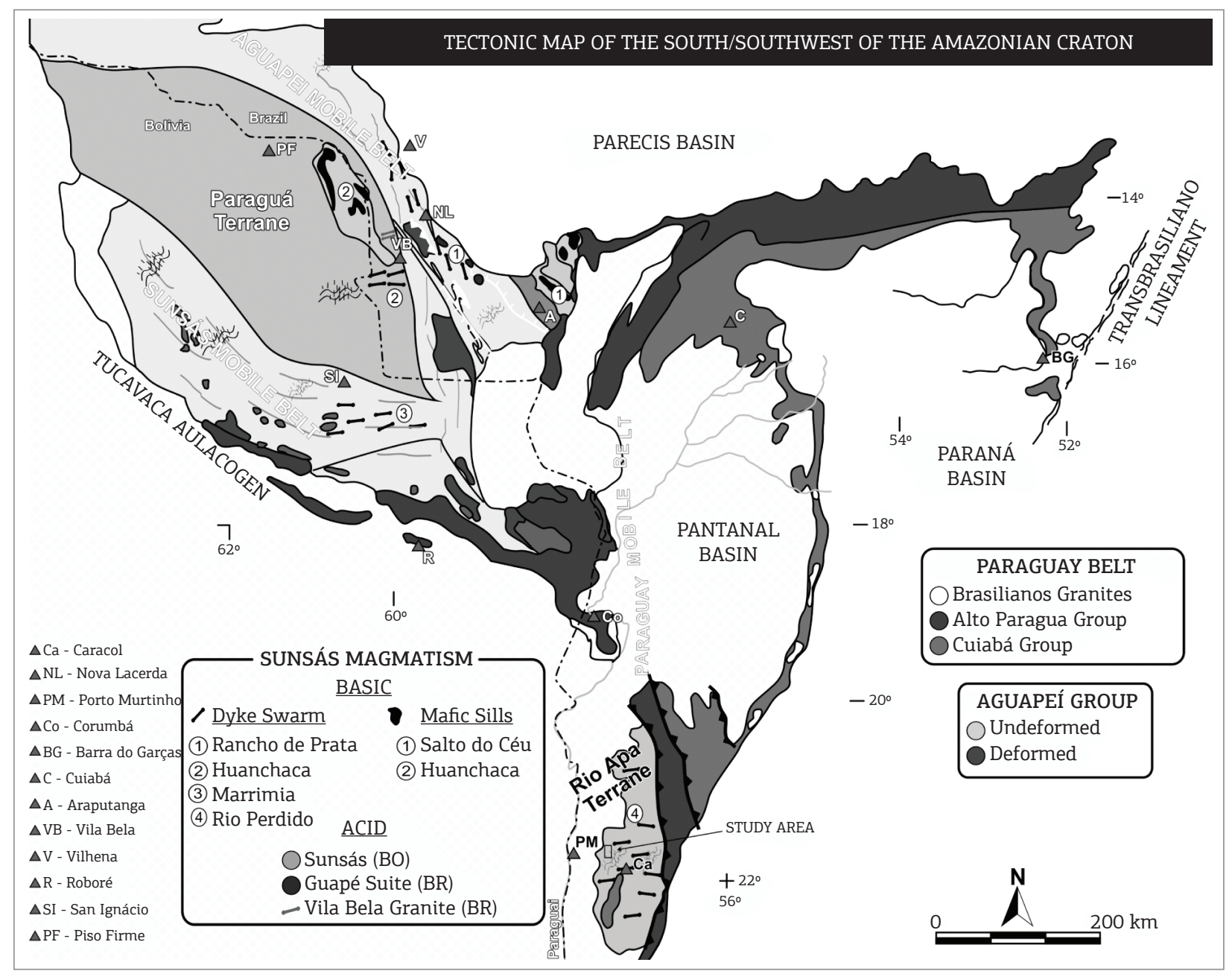

Figure 1. Tectonic map of the south/southwest of the Amazonian Craton. Extracted from Ruiz et al. (2010).

Intrusive Suite indicated an age of 1,867 Ma; the same dating procedure applied to samples of rhyodacite from the Serra da Bocaina Volcanic Suite provided an age of 1,794 Ma (Lacerda Filho et al. 2006).

Whole-rock Sm-Nd isotopic data (Tab. 1) revealed a model age (TDM) of $2.17 \mathrm{Ga}$ for the Alumiador Intrusive Suite and a TDM of 2.26 Ga for the volcanic rocks; each of these present slightly negative $\varepsilon_{\mathrm{Nd}(\mathrm{T})}$ values of approximately -0.68 and -2.0 , respectively (Lacerda Filho et al. 2006).

Whole rock Rb-Sr dating (Tab. 1) performed on volcanic rocks provided an age of 1,650 $\pm 63 \mathrm{Ma}$ (isochronous reference), with a low initial value of $\mathrm{Sr}\left({ }^{87} \mathrm{Sr} /{ }^{86} \mathrm{Sr}=0.702 \pm 0.004\right)$; the same process performed on the granitoids yielded a $\mathrm{Rb}-\mathrm{Sr}$ age (RT) of 1,600 $\pm 40 \mathrm{Ma}$ (isochronous reference), with a ${ }^{87} \mathrm{Sr} /{ }^{86} \mathrm{Sr}$ ratio of $0.707 \pm 0.004$ (Araújo et al. 1982). $\mathrm{Rb}-\mathrm{Sr}$ determinations presented by Cordani et al. (2005) for granitoids from the Alumiador Intrusive Suite indicated ages ranging from 1,650 to $1,700 \mathrm{Ma}$.
Ar-Ar and K-Ar results presented by Cordani et al. (2010) in several lithostratigraphic units comprising the Rio Apa Terrane indicated values of approximately $1,300 \mathrm{Ma}$ (Tab. 1).

\section{FIELD ASPECTS}

The FSB rocks are in tectonic contact (Santa Rosa Shear Zone) with the Carandá Granite, and on the north, south and west, the FSB is covered by unconsolidated sediments of the Pantanal Formation (Fig. 3). The Carandá Granite consists of biotite syenogranites with medium inequigranular texture that is foliated to massive; it is composed of leucocratic, greenish gray rocks and consists of microcline, plagioclase, quartz and mafic concentrations with biotite as the only essential primary mafic.

Geological mapping and petrographic analysis identified five petrographic facies in the study area (Fig. 3). One of these petrographic facies is effusive (facies 5) and four 


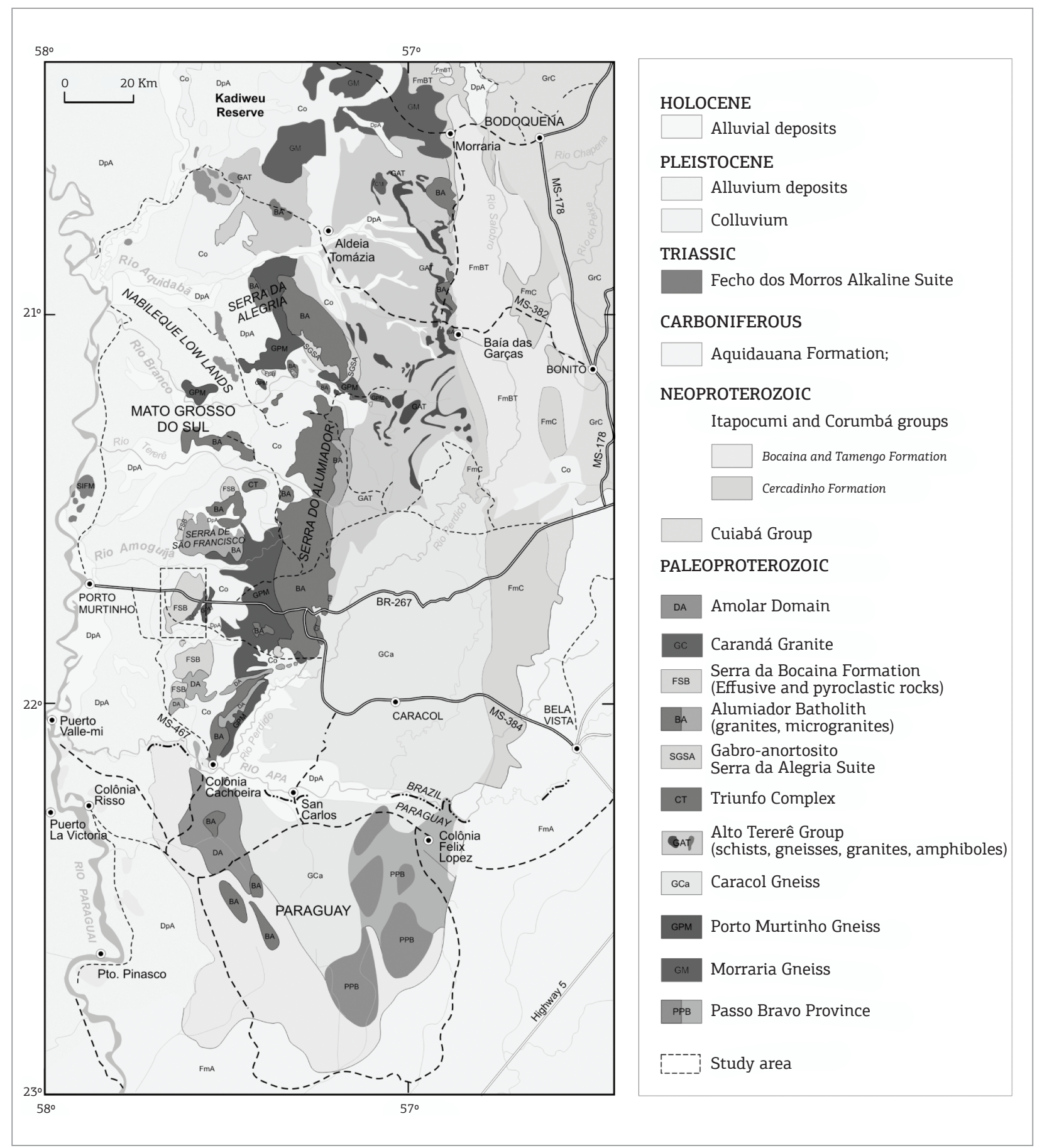

Figure 2. Geological diagram of the Rio Terrane in southwestern Mato Grosso do Sul (Brazil) and northwestern Paraguay. Extracted and modified from Cordani et al. (2010).

Table 1. Summary of the isotopic results available for the rocks of the Amoguijá Magmatic Arc

\begin{tabular}{l|c|c|c|c|c}
\hline Units of the Amoguijá Magmatic Arc & U-Pb (Ma) & Sm-Nd (TDM) & $\varepsilon_{\mathbf{N a}(\mathrm{T})}$ & $\mathbf{R b}-\mathbf{S r}(\mathbf{M a})$ & $\mathbf{A r}-\mathbf{A r}(\mathbf{M a})$ \\
\hline Serra da Bocaina Formation & $1,794^{*}$ & $2.26 \mathrm{Ga}^{*}$ & $-2.0^{*}$ & $1,650 \pm 63^{*}$ & $1,300^{+}$ \\
\hline Alumiador Intrusive Suite & $\begin{array}{c}1,867^{*} \\
1,839 \pm 33^{+}\end{array}$ & $2.17 \mathrm{Ga}^{*}$ & $-0.68^{*}$ & $1,600 \pm 40^{*}$ & $1,300^{+}$ \\
\hline
\end{tabular}

*Araújo et al. (1982); "Lacerda Filho et al. (2006); 'Cordani et al. (2010). 
are pyroclastics - ignimbrite breccia (facies 1 ), ignimbrite rich in crystals (facies 2), co-ignimbrite tuff (facies 3 ) and rheoignimbrite (facies 4).

The ignimbrite breccia facies of the FSB dominates the highest and central portion of the Serra da Bocaina, encompassing lenses/layers and fragments of co-ignimbrite tuff (Fig. 3). This facies maintains tectonic contact with the Carandá Granite in the ductile shear zone, and the two units are partially covered — in unconformity — by sediments from the Pantanal Formation. The rocks of this facies show grayish, greenish, reddish and purplish colors and are characterized by a substantial amount of lithic fragments of various sizes, shapes and compositions. The fragments are ellipsoidal, rounded and angular with sharp to irregular contacts and range in size from 0.3 to $15.0 \mathrm{~cm}$; some fragments consist of phenocrysts of quartz,

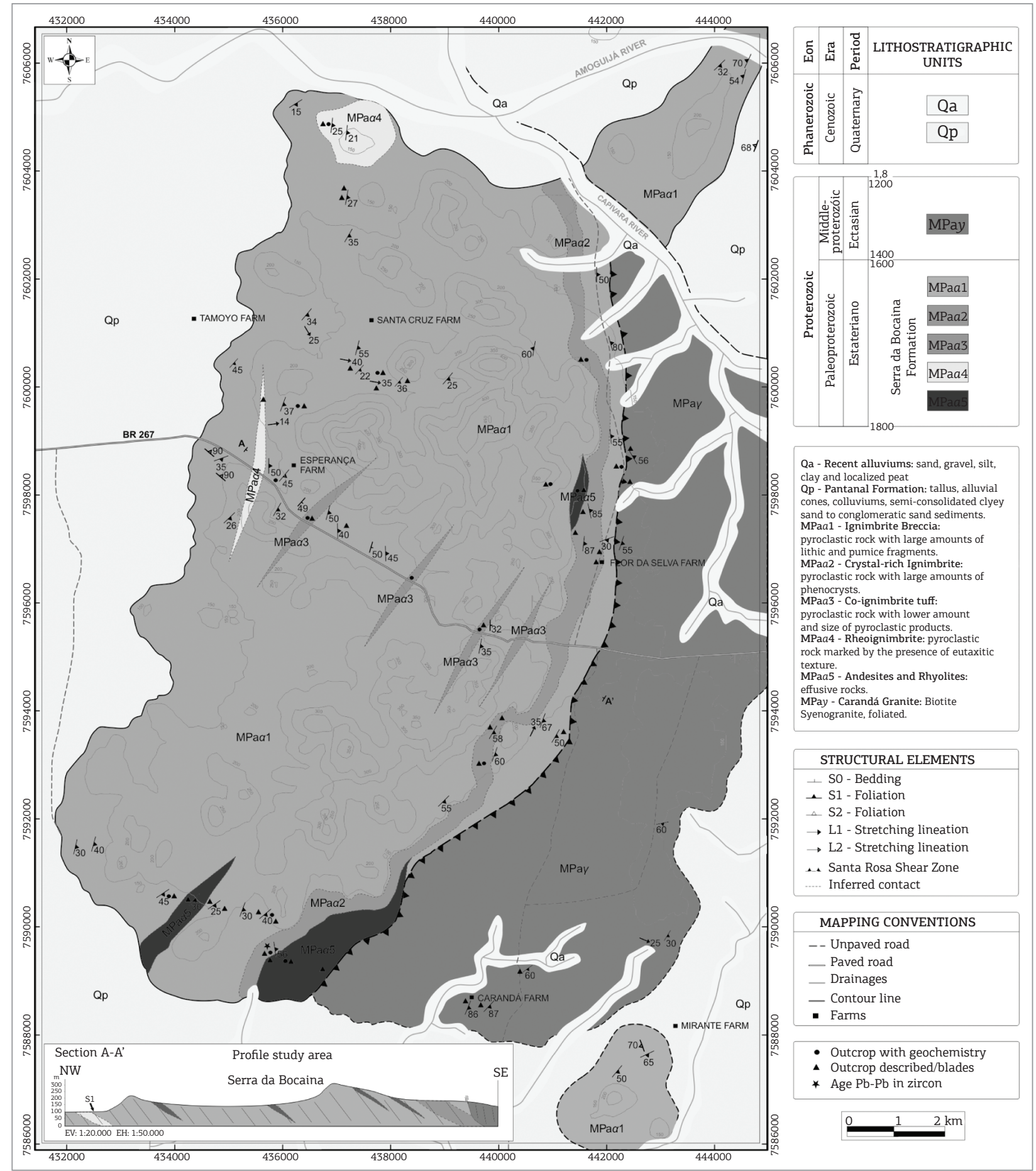

Figure 3. Geological map and cross-section of the Serra da Bocaina Formation, Porto Murtinho (MS). 
plagioclase, alkali feldspar and, sometimes, amygdaloidal rocks. Phenocrysts of quartz, plagioclase and alkali feldspar are typically immersed in a fine to coarse ash matrix. The juvenile crystal clasts identified in this facies are of the same composition as the phenocrysts.

The crystal-rich ignimbrites occupy the northeast and southeast portions of the study area, measuring approximately $15 \mathrm{~km}$ length and $1 \mathrm{~km}$ in width (Fig. 3); these ignimbrites outcrop as blocks and tiles and maintain sharp contact to the east and the west with the rocks of facies 1 . They are dark gray in color and composed of quartz, plagioclase and alkali feldspar phenocrysts immersed in fine cineritic matrix. The crystal clasts, when visible to the naked eye, are composed of quartz and plagioclase, with sizes always smaller than $1.0 \mathrm{~mm}$; pumice and fiammes are hardly perceptible in macroscopic samples.

The co-ignimbrite tuff facies occurs as lenses/layers in the central portion of the range (Fig. 3); it consists of fragments of facies 1 and exhibits sharp contacts with it. The lenses/layers outcrop in road cuts with thickness measurements ranging between $2.5 \mathrm{~cm}$ and $1 \mathrm{~m}$; these form a homoclinal structure dipping SE, and the fragments appear in various shapes and in sizes between 0.5 and $25 \mathrm{~cm}$. When altered, the rocks of this facies show greenish to whitish colors and distinguish themselves from the other facies by the lower amount and smaller size of phenocrysts/ crystal clasts and pyroclastic products that are not visible to the naked eye.

The rheoignimbrites occur in two distinct portions of the study area - one to the north and the other to the west (Fig. 3) - and typically outcrop in small tiles. These rocks are dark gray in color with paragenesis essentially formed by quartz, plagioclase and, subordinately, alkali feldspar. The lithoclasts have a similar composition as those of facies 1 with smaller proportions and dimensions (between 0.3 and $2.0 \mathrm{~mm}$ ). The crystal clasts observed are of the same composition as the phenocrysts and are approximately 1.0 $\mathrm{mm}$ in size. The pyroclastic products, such as pumice and fiammes, are difficult to identify in macroscopic samples, which is similar to the other facies.

Facies 5 correspond to the andesitic and rhyolitic lavas; they outcrop in two different portions of the study area and define a shallow relief in the Serra da Bocaina (Fig. 3). A smaller portion of facies 5 presents in the central portion of the range and another is located to the south, where it is partially covered by sediments from the Pantanal Formation. It is orange-red to greenish-gray in color in hydrothermally altered samples and rich in epidote; it has a porphyritic to glomeroporphyritic texture with a fine to coarse ash matrix. Well-formed crystals of plagioclase of submillimetric sizes stand out and are sometimes replaced by epidote, quartz, amphibole and more rarely, alkali feldspar. All samples collected in the southern portion of the area show evidence of pervasive hydrothermal processes, such as epidotization, chloritization and saussuritization.

\section{PETROGRAPHY}

The rocks from facies 1 (ignimbrite breccia) of the FSB are characterized petrographically by large amounts of lithic and pumice fragments, crystal clasts, pumices, fiammes, shards and crystallites of varied dimensions and compositions, which are found immersed in a fine cineritic matrix of felsic nature with several degrees of alteration. Phenocrysts of plagioclase, quartz and (subordinately) alkali feldspar, with high-temperature biotite as the main mafic, may also be identified. Alteration phases are represented by sericite, epidote/clinozoisite, calcite, clay minerals and chlorite; accessories are represented by allanite, zircon, apatite and opaques. The biotite is characterized by acicular/fibrous to fibro-radiated habit, by small plates disseminated throughout the matrix (Fig. $4 \mathrm{H}$ ), or by plates forming aggregates with chlorite and glass. The allanite is euhedral, isotropic, metamictic, and partially replaced by epidote. Devitrification products may be observed both in the mesostasis and in the lithoclasts and pumices, in addition to the interior of veins/fractures filled with silica. The lithic fragments are rounded or angular to elongated, with varying contours, millimetric to centimetric in size (but larger than the pumices) and are usually composed of a felsic mesostasis, phenocrysts, biotite, opaques, glass and devitrification products (including spherulite, axiolite, crystallites and graphic feldspars). They may represent cognate terms of similar composition as the rock, characterizing portions of the same magma, which is why they maybe classified as lithic accessories (Fig. 4A); conversely, they may not show similarities with the rock and correspond to accidental lithic fragments. The phenocrysts are euhedral, subhedral and anhedral; they are between 0.2 and $2.5 \mathrm{~mm}$ in size and show different degrees of alteration, fracturing, embayment and corrosion gulfs filled with the matrix or glass. In certain samples, the phenocrysts appear completely fragmented as a result of the extrusive process and because of cooling and hydration. The plagioclase exhibits polysynthetic (albite and pericline) and complex baveno twinning, which are sometimes only relicts because of the intense hydrothermal processes, such as sericitization, saussuritization and argillization. The facies may appear clean or only as pseudomorphs filled with epidote, sericite, calcite, clay minerals, chlorite and biotite. Quartz is common in this facies and appears embayed with intense magmatic 

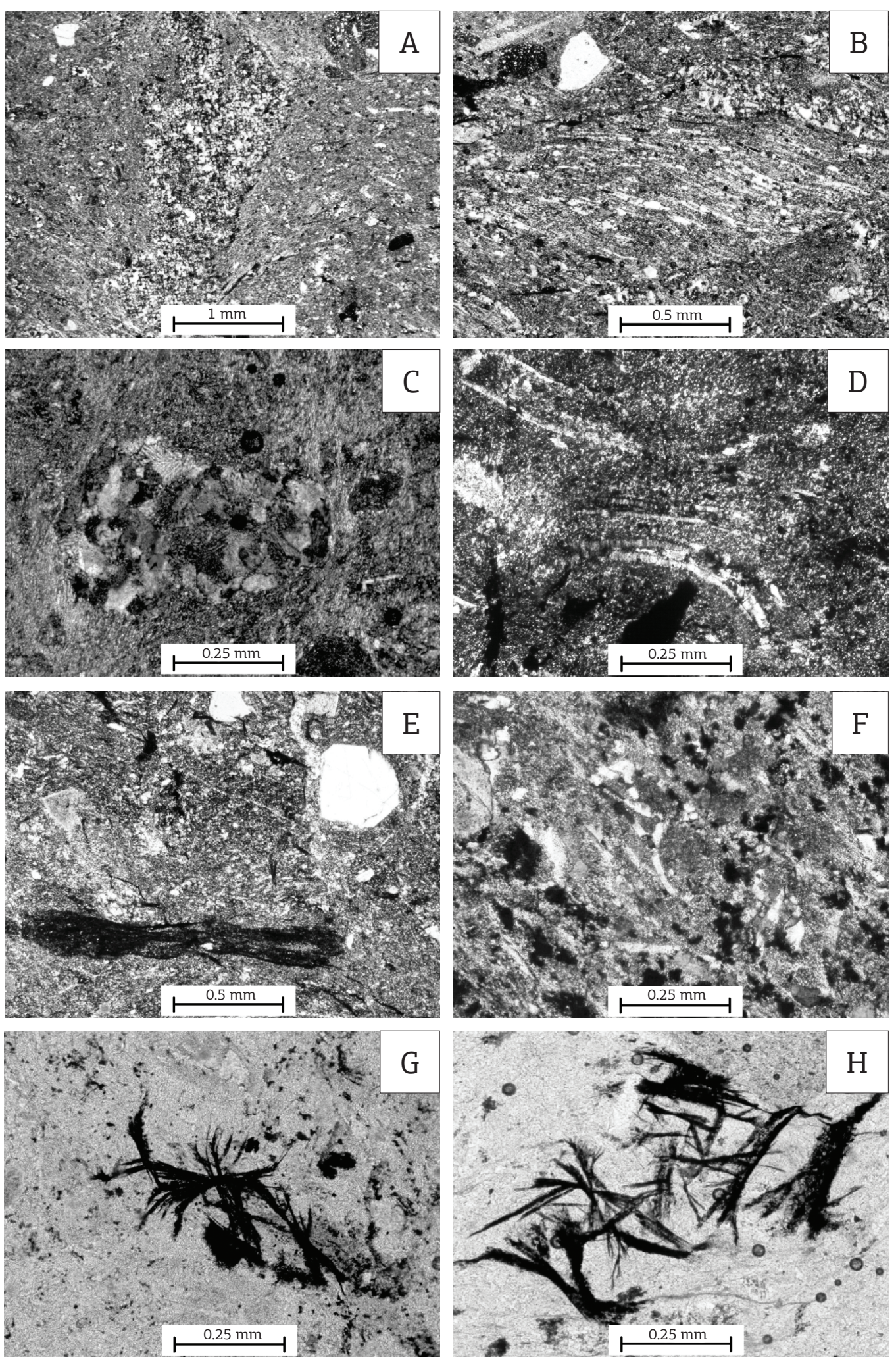

Figure 4. Photomicrographs of Serra da Bocaina Formation rocks illustrating: (A) lithic accessory rich in spherical spherulites in fine cineritic matrix; (B) ellipsoidal pumice and quartz crystal clast; (C) pumice perpendicular to the foliation given by the parallel arrangement of the sericite; (D) tube pumices in glassy to cineritic mesostasis; (E) collapse fiamme, high-temperature biotite and crystal clasts in cineritic matrix; (F) "Y" type shards and glass; (G) dark brown to black acicular glass; and $(\mathrm{H})$ acicular to fibro-radiated habit biotite and glass. Crossed polarizers in $\mathrm{A}, \mathrm{B}, \mathrm{C}, \mathrm{D}, \mathrm{E}$ and $\mathrm{F}$ and parallel in $\mathrm{G}$ and $\mathrm{H}$. 
corrosion. Alkali feldspars are present with Carlsbad or grid twinning - characterizing orthoclase and microcline, respectively - and often with graphic to granophyric intergrowth. The essential crystal clasts identified in this facies appear angular to rounded and consist of plagioclase, alkali feldspars and quartz, which are normally embayed. Pumices have well-defined outlines with rounded, ellipsoidal (Fig. 4B), flat (Fig. 4C) or elongated shapes and shards, crystallites, canaliculi and fibrous fragments may be identified inside them; they generally are recrystallized as feldspar and quartz arrangements (at times graphic or granophyric), and tube pumices (Fig. 4D) are often identified. The fiammes, which are collapsed pumices, are often stretched and oriented (Fig. 4E); they are identified by darker colors and a greater degree of flattening because of alterations that accompany the welding process. Shards generally occur in the matrix and fragments, with typical "X" and "Y" (Fig. 4F) shapes and in plates. Dark brown to black relict glass may be observed in fibro-radiated arrangement that is dispersed throughout the matrix (Fig. 4G) and in lithoclasts.

The devitrification products involve the growth of fibrous microliths and are represented by axiolite-type spherulites that are composed of fibro-radiated crystals developed from line, fan, bow tie, spherical, and lithophysae structures.

Facies 2 (crystal-rich ignimbrites) differ optically by the large proportion of phenocrysts and crystal clasts that reach up to $50 \%$ of the total composition (Fig. $5 \mathrm{~A}$ ); these present a lower percentage of the other pyroclastic products earlier described, a large amount of chlorite, a large amount of carbonates and the absence of high-temperature biotite. Facies 2 phenocrysts and crystal clasts (Fig. 5B) have the same composition as those found in the other ignimbrite facies but with larger sizes, ranging between 0.5 and $4.0 \mathrm{~mm}$ and 0.2 and $0.5 \mathrm{~mm}$, respectively.

The ignimbrite tuff (facies 3 ) is characterized by particles elutriated from the ignimbrite flow and differs from the other facies by the smaller amount and size of its phenocrysts/crystal clasts and pyroclastic products $(<0.1 \mathrm{~mm})$, by more homogeneous and even finer mesostasis, by the absence of high-temperature biotite, and by showing foliation as a result of the parallel arrangement of sericite (Fig. 5C).

The rheoignimbrites (facies 4) are characterized by post-compaction flow features of a welded ignimbrite that remained hot long enough to be ductilly deformed. The striking difference between this facies and the others is its eutaxitic texture (Fig. 5D and E), its ellipsoidal and sigmoidal pumices and by the large amount of devitrification products. The lithoclasts and pumices have a similar composition as those found in facies 1 but present in smaller proportions and dimensions (between 0.3 and $2.0 \mathrm{~mm}$ ). Brittle/ductile deformation was also observed in these rocks, such as microveins of approximately $0.2 \mathrm{~mm}$ that are perpendicular to the foliation, broken and displaced, sometimes folded, and filled by epidote or sometimes by silica.

Facies 5 corresponds to lavas with porphyritic to glomeroporphyritic texture and andesitic to rhyolitic composition. The phenocrysts in the rhyolites are quartz, alkali feldspar and plagioclase, generally euhedral to subhedral with evidence of intense magmatic corrosion (such as embayment and gulfs); they are immersed in a very fine to fine matrix of the same composition, with apatite, zircon and opaques as accessories and sericite, epidote/clinozoisite, chlorite, and clay minerals as alteration phases.

Phenocrysts of amphibole and mainly of altered and pseudomorphed plagioclase occur in the andesites in a very fine matrix with pervasive chloritization and sericitization and a small amount of preserved primary minerals, such as amphibole and biotite; at times, an accidental microgranular enclave of a more acidic composition is observed in these lithotypes. The plagioclase in the rhyolites has an albitic composition and occurs in the matrix as tiny grains, crystallites or isolated phenocrysts that sometimes form glomerocrysts (Fig. 5F); they are subhedral of tabular habit, zoned, sometimes myrmekitic, with albite and/ or pericline twinning, and they locally present numerous corrosion gulfs that give them a sieve texture (Fig. 5G). In the andesites, the plagioclase is found in the matrix in thin laths, which sometimes describe a slight flow texture that is intensely sericitized, and in phenocrysts of a composition similar to andesine, generally twinned and zoned with greater degree of alteration in the nucleus; it usually occurs partially or completely pseudomorphed by an association of microgranular to fibro-radiated epidote, chlorite, sericite and calcite. The quartz in rhyolites occurs both in the matrix and in embayed phenocrysts; sometimes it is recrystallized in a mosaic, in thin veins or as vermicular intergrowth in the plagioclase and alkali feldspar, which forms myrmekitic and graphic textures, respectively. In the andesites, quartz is always in the secondary phase and can occur in very fine grains, associated with epidote and chlorite; it is derived from the plagioclase transformation. The alkali feldspars are common phases only in the rhyolites and are found in the felsic matrix or as phenocrysts; sometimes, they form glomerocrysts. They are always perthitic and are represented by subhedral to anhedral crystals of microcline with grid twinning and by orthoclase with Carlsbad twinning, both partially altered to sericite and clay minerals.

The only primary mafic found in the rhyolites is biotite, which is observed in tiny plates dispersed in the matrix or in aggregates of fibro-radiated crystals associated with 

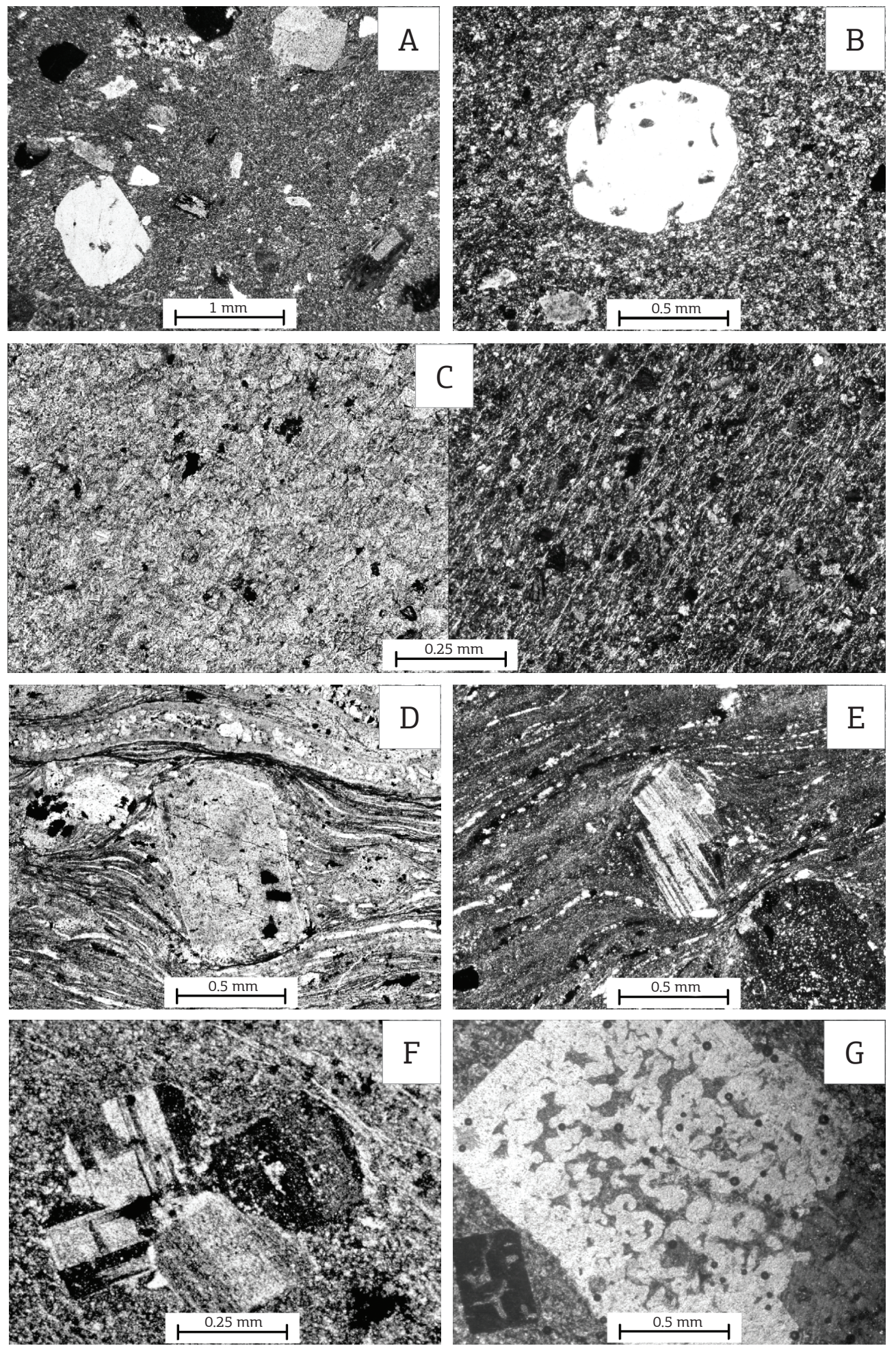

Figure 5. Photomicrographs of Serra da Bocaina Formation rocks illustrating: (A) phenocrysts, crystal clasts and pumice immersed in cineritic fine matrix; (B) quartz phenocryst with corrosion edges and gulfs in lithotypes of larger granulation matrix; (C) foliation given by the parallel arrangement of sericite and crystal clast; (D) plagioclase phenocryst involved by eutaxitic texture and fiammes; (E) eutaxitic texture surrounding subhedral crystal of turbid plagioclase; $(F)$ plagioclase glomerocryst; and $(G)$ plagioclase phenocryst with corrosion gulfs characterizing sieve texture. Crossed polarizers in A, B, E, F and G, parallel in D and parallel to the right and crossed to the left in $\mathrm{C}$. 
opaques. As for the andesites, they have euhedral to subhedral phenocrysts of greenish-brown amphiboles as mafics, which is identified as hornblende, and a large amount of epidote/clinozoisite and chlorite forming the matrix and as pseudomorphs of plagioclase phenocrysts.

The hydrothermal phase is characterized in the FSB rocks by sericitization, epidotization, saussuritization, argillization and chloritization, and metamorphism of greenschist facies is identified by the paragenesis albite + epidote + chlorite.

\section{STRUCTURAL ANALYSIS}

The semi-detailed geological mapping of the FSB defined a set of ductile and brittle-ductile tectonic structures that may be grouped into two deformation stages that are designated $\mathrm{F}_{1}$ and $\mathrm{F}_{2}$.

Despite the tectonic-metamorphic imprint, primary relict structures $\left(S_{0}\right)$ are preserved that are mainly characterized by centimetric lenses/layers of co-ignimbrite tuff interspersed with ignimbrite breccias. The lenses/layers show dips between $20^{\circ}$ and $50^{\circ} \mathrm{SE}$ and ESE (Fig. 6A) and form an angle with the $S_{1}$ foliation, which has dips that concentrate between $30^{\circ}$ and $65^{\circ} \mathrm{SE}$. The $S_{0}$ measurements show a maximum concentration of $100 / 30$, which suggests an arrangement of the homocline type with slight waves produced by refolding.

The first deformation stage $\left(\mathrm{F}_{1}\right)$, which is the oldest and most intense event, may be observed throughout the extension of the Serra da Bocaina in both the pyroclastic and effusive lithotypes and is responsible for the development of the penetrative foliation $S_{1}$. In the FSB, the $S_{1}$ foliation is represented by schistosity in the rocks of facies 1 (Fig. 6B), 2, 4 and 5 and by slaty cleavage in facies 3 (Fig. 7A). It is associated with deformation stage $\mathrm{F}_{1}$, which was the onset of the Santa Rosa Shear Zone and placed the Carandá Granite in contact with facies 1 and the effusive rocks of the FSB.
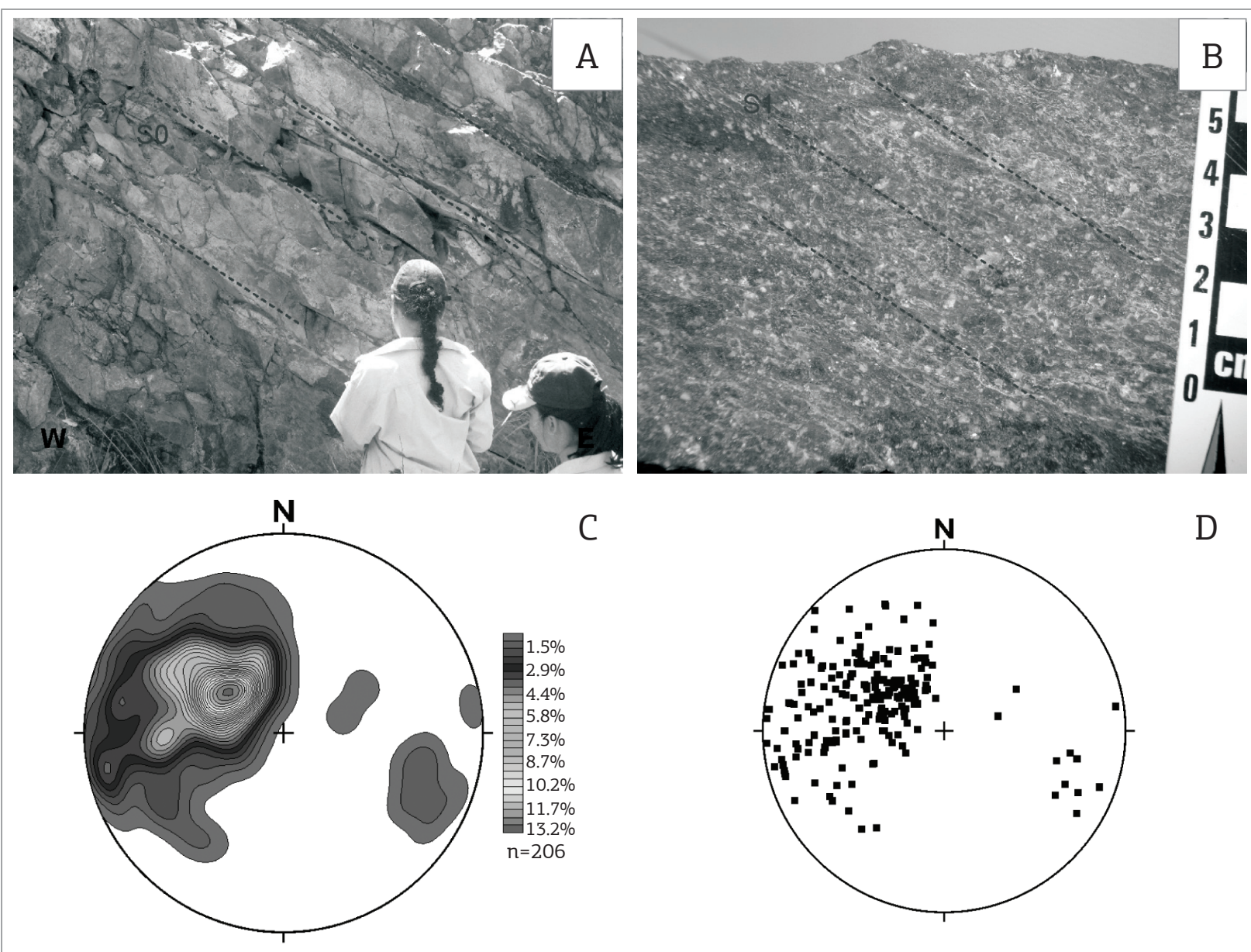

D

Figure 6. Figures illustrating: (A) lenses/layers of facies 3 in vertical cut at Serra da Bocaina, highway BR-267; (B) $\mathrm{S}_{1}$ foliation evidenced by phenocrysts, crystal clasts and stretched oriented fragments of the rocks of facies 1 ; and (C and D) stereograms of penetrative foliation $\mathrm{S}_{1}$ for the FSB rocks, isofrequency and pole diagrams, respectively. 
The $S_{1}$ foliation is defined by oriented recrystallization of platy minerals, especially sericite, that formed films oriented according to the foliation plane, in addition to the flattening and rotation of the matrix crystal clasts and phenocrysts of quartz, plagioclase, and alkali feldspars (Fig. 7B).

The stereogram for the $S_{1}$ foliation poles points to a maximum of approximately $120 / 40$ and a dispersion of measurements between 030/35 and 150/70 (Figs. 6C and D); this is most likely the result of the folding of the second stage of deformation $\mathrm{F}_{2}$.

Lineations $\mathrm{L}_{1}$ (mineral and stretching) are defined by the elongation of the phenocrysts and lithic fragments. The measurements show attitudes ranging from 030/35 and $150 / 20$.

The Santa Rosa Shear Zone is located on the eastern edge of the Serra da Bocaina and is characterized by a continuous and anastomosed belt of ductile deformation that is observed in the Carandá Granite and in facies 2 of the FSB. The mylonites generated in the FSB are characterized by the preferential orientation of the matrix, by the flattening and rotation of porphyroclasts (Fig. 7C), by crystal clasts and by lithic fragments. Mylonitic foliation (Fig. 7D) shows an average attitude of $085 / 80$, which is similar to the stretching lineation attitude (088/80). Kinematic indicators observed in the field and in thin sections point to a reverse movement with top transportation to the WNW; thus, the Santa Rosa Shear zone tectonically placed the Carandá Granite over the pyroclastic and effusive rocks of the FSB along a reverse frontal slope.

The second deformation event $\left(\mathrm{F}_{2}\right)$, which was less intense, is characterized by the generation of folds in the $S_{1}$ foliation. The microfolds are open, symmetric to slightly asymmetric, and oriented toward the NNW/SSE, verging weakly to NW.

The $S_{2}$ foliation is mainly represented by a crenulation cleavage or disjunctive cleavage with an average attitude of $220 / 90$, which are both related to the axial plane of the $\mathrm{D}_{2} \mathrm{mi}-$ crofolds and mesofolds. The $\mathrm{L}_{2}$ intersection lineation has an attitude of $110 / 45$ and corresponds to the axis of the $\mathrm{D}_{2}$ folds.
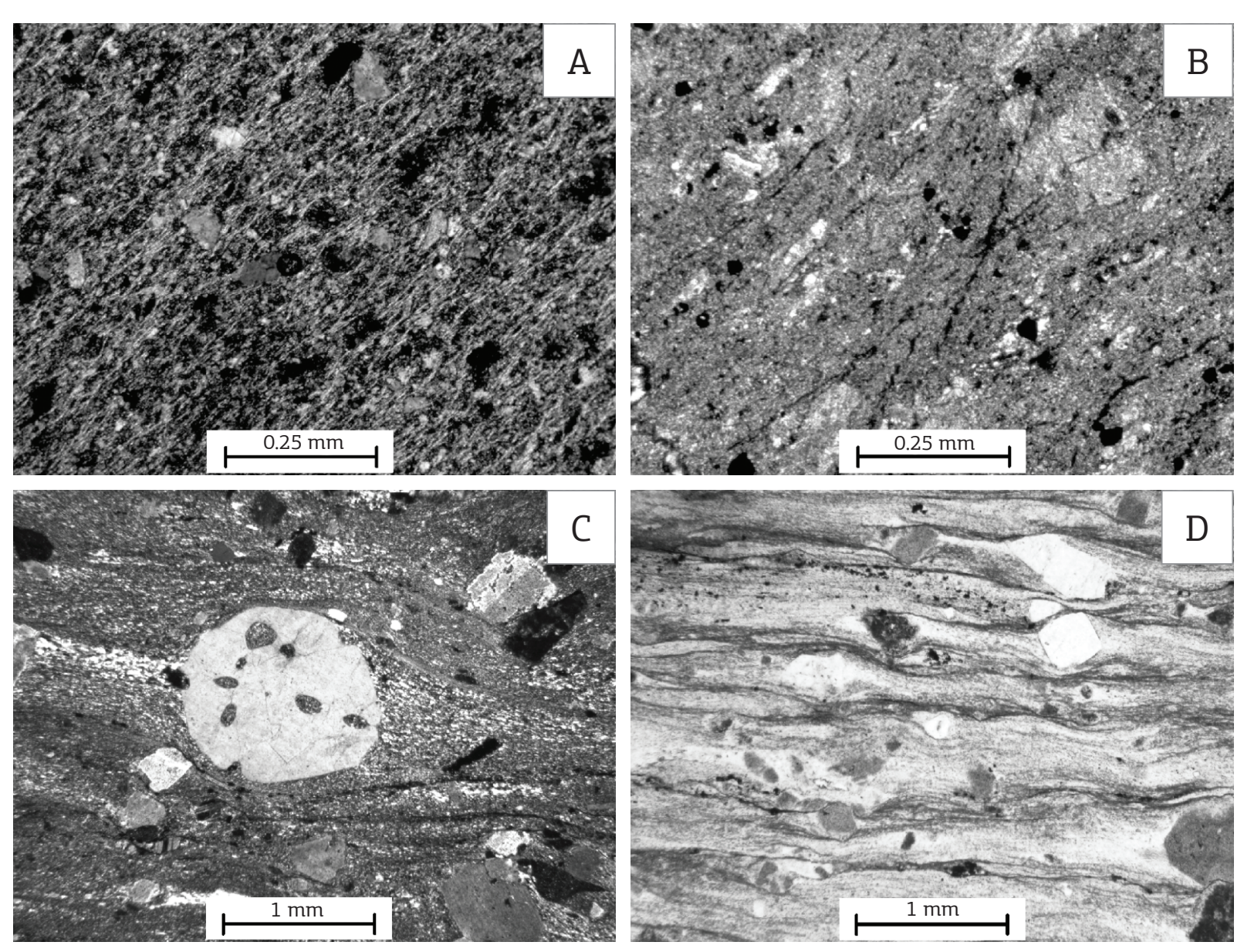

Figure 7. Photomicrographs of the Serra da Bocaina Formation rocks illustrating: (A) slaty cleavage in the rocks of facies 3; (B) phenocrysts and lithic fragments oriented according to foliation $\mathrm{S}_{1}$; (C) rounded quartz phenocryst with corrosion gulfs and pressure shadow indicating the deformation movement $F_{1}$; and (D) mylonitic foliation in rock of facies 2. Crossed polarizers in A, B and C and parallel in D. 
The FSB displays greenschist facies metamorphism, which is characterized by the paragenesis albite + epidote + chlorite and related to the $\mathrm{F}_{1}$ deformation stage, whereas the retro-metamorphism features must be associated with the second stage of deformation $\mathrm{F}_{2}$, which was developed at a shallow crustal level.

\section{GEOCHEMISTRY}

Twenty-four samples of FSB rocks were selected for the lithogeochemical treatment, including 9 from facies 1 , 4 from facies 2, 4 from facies 3, 2 from facies 4, 3 from facies 5 and 2 from lithic fragments. It is important to note that the ignimbrite breccia samples were treated by manual sorting that attempted to separate the fragments for analysis in isolation, in addition to the matrix. After this stage, all samples were treated in the Laboratory of Sample Preparation of the Mineral Resources Department of the Federal University of Mato Grosso (Departamento de Recursos Minerais da Universidade Federal de Mato Grosso - DRM/UFMT) and analyzed at the Acme Analytical Laboratories (Acmelab) in Vancouver (Canada) by ICP-ES and ICP-MS for major, minor and trace elements, including rare earths (Tabs. 2 to 4). They were calcined to constant weight to calculate the loss on ignition; the major elements and certain minor elements were recalculated in anhydrous base, as recommended by the IUGS (Le Maitre 2002).

Most of the lithotypes of the different facies defined in this study present an acidic nature, relative compositional homogeneity and $\mathrm{SiO}_{2}$ values ranging between 71.85 and $78.31 \%$. Only two lava samples (AB26), which were intermediate in character, were an exception to this pattern; these had $\mathrm{SiO}_{2}$ content between 60.38 and $60.62 \%$, which corresponds to andesite and causes a compositional gap between these values and the $71.85 \%$ silica; this is most likely the result of inadequate sampling and/or outcropping. The rock fragment samples of the ignimbrite breccia are even more acidic, with a $\mathrm{SiO}_{2}$ content of approximately $78 \%$, which proves to be geochemically similar to the other pyroclastics.

Harker diagrams of the FSB rocks (Fig. 8) show well-defined evolutionary patterns with negative linear correlations between silica and $\mathrm{Al}_{2} \mathrm{O}_{3}, \mathrm{CaO}, \mathrm{MgO}, \mathrm{TiO}_{2},\left(\mathrm{Fe}_{2} \mathrm{O}_{3}\right)$ , $\mathrm{P}_{2} \mathrm{O}_{5}$ and $\mathrm{MnO}$ because of the progressive depletion in plagioclase and primary mafic minerals during magmatic differentiation, such as hornblende, biotite, ilmenite-magnetite, titanite and apatite. The diagrams involving alkalis showed relative dispersion that resulted from the greater mobility of these elements during the post-magmatic processes. Among the trace elements, only the Sr showed a negative correlation with silica (Fig. 8), which corroborates the idea of plagioclase fractionation.

The rocks of facies 1 to 4 and the lithic fragments of the FSB are classified as rhyolites, whereas the lavas (corresponding to facies 5) are plotted in the rhyolite and andesite fields when the total alkalis versus silica diagram is considered Le Bas (1986) (Fig. 9A). Similarly, the points representing these lithotypes coincide with the rhyolite and andesite domains in the $\mathrm{SiO}_{2}$ by contrast to the $\mathrm{Zr} / \mathrm{TiO}_{2}$ diagram proposed by Winchester \& Floyd (1977) (Fig. 9B); the pyroclastics and lavas plot in the rhyolites/alkali-rhyolite and lati-andesite fields in the R1-R2 diagram (De La Roche et al. 1980) (Fig. 9C), respectively, where $\mathrm{R} 1=4 \mathrm{Si}-11(\mathrm{Na}+\mathrm{K})-$ $2(\mathrm{Fe}+\mathrm{Ti})$ and $\mathrm{R} 2=6 \mathrm{Ca}+2 \mathrm{Mg}+\mathrm{Al}$.

The TAS and AFM diagrams of Irvine \& Baragar (1971), illustrated in Fig. 9A and 10A, respectively, indicate that the magmatism that generated the studied rocks is characterized as subalkaline and calc-alkaline. This affinity is also suggested because the La/Yb ratios are higher than 6 (Tabs. 2 to 4), as proposed by Barret \& MacLean (1999), whereas the calc-alkaline nature of medium to high- $\mathrm{K}$ is illustrated in the $\mathrm{K}_{2} \mathrm{O}$ by contrast to the $\mathrm{SiO}_{2}$ diagram by Le Maitre (2002) (Fig. 10B). As for alumina saturation, the representative points of the FSB rocks and fragments classify this magmatism as peraluminous in the $\mathrm{A} / \mathrm{CNK}$ by contrast to the $\mathrm{A} / \mathrm{NK}$ diagram by Maniar \& Piccoli (1989) (Fig. 10C), with the exception of a matrix sample from the Ignimbrite Breccia Facies (AD 2/2M) that plots in the metaluminous domain.

In diagrams that discriminate tectonic environments based on the behaviors of $\mathrm{Hf}-\mathrm{Rb}-\mathrm{Ta}$ and of $\mathrm{Rb}$ and $(\mathrm{Y}+\mathrm{Nb}$ ) proposed by Harris et al. (1986) (Fig. 11A) and Pearce (1996) (Fig. 11B), respectively, the points representing the FSB rocks coincide with the domain of volcanic arc granitoids.

The content normalization of certain trace elements and $\mathrm{K}_{2} \mathrm{O}$ of the pyroclastic and effusive rocks of the FSB shows an enrichment of large-ion lithophile elements (LILE) in relation to the high field strength elements (HFSE), based on the granites of the Meso-Oceanic Range (Pearce et al. 1984) (Fig. 12A). In the HFSE, lower values than those from the high-K calc-alkaline series are typically observed.

The layout of the rare earth element (REE) concentrations in the FSB rocks, normalized by the C1 chondritic values (Sun \& McDonough 1989) (Fig. 12B), shows no anomalies to moderately negative $\mathrm{Eu}$ anomalies that correspond to $\mathrm{Eu} / \mathrm{Eu}^{*}$ ratios between 0.56 and 1.03 (Tabs. 2 to 4). It shows a fractionation pattern of heavy REE (HREE) in relation to light REE (LREE) and La/Yb ratios between 5.03 and 16.98 (Tabs. 2 to 4), which exhibit a sub-horizontal configuration for the HREE.

The trace element values of the FSB andesites (hydrothermally altered facies 5) are always lower than those of 
Serra da Bocaina Formation: Rio Apa Terrane

Table 2. Chemical composition of major, minor (\% weight), and trace elements, including rare earth elements (ppm), of rocks from the Serra da Bocaina Formation

\begin{tabular}{|c|c|c|c|c|c|c|c|c|}
\hline Samples & AB26(1) & AB26 & AD01 & AD85 & AD92 & AD65 & $\mathrm{AD2} / 2 \mathrm{M}$ & AD32(2) \\
\hline Facies & 5 & 5 & 4 & 1 & 1 & 1 & 1 & 1 \\
\hline $\mathrm{SiO}_{2}$ & 60.38 & 60.62 & 71.85 & 72.9 & 73.46 & 73.97 & 75.10 & 75.18 \\
\hline $\mathrm{TiO}_{2}$ & 0.70 & 0.68 & 0.45 & 0.42 & 0.33 & 0.34 & 0.28 & 0.24 \\
\hline $\mathrm{Al}_{2} \mathrm{O}_{3}$ & 19.28 & 18.98 & 13.99 & 13.31 & 14.08 & 14.74 & 13.11 & 12.57 \\
\hline $\mathrm{Fe}_{2} \mathrm{O}_{3}$ & 5.44 & 5.65 & 3.01 & 3.51 & 1.75 & 1.84 & 1.55 & 2.72 \\
\hline $\mathrm{MnO}$ & 0.14 & 0.14 & 0.09 & 0.09 & 0.10 & 0.04 & 0.03 & 0.07 \\
\hline $\mathrm{MgO}$ & 2.03 & 1.88 & 0.68 & 0.69 & 0.39 & 0.52 & 0.25 & 0.22 \\
\hline $\mathrm{CaO}$ & 5.08 & 5.04 & 1.09 & 1.32 & 1.51 & 0.12 & 0.79 & 0.39 \\
\hline $\mathrm{Na}_{2} \mathrm{O}_{3}$ & 4.51 & 4.75 & 4.60 & 3.58 & 3.07 & 4.15 & 5.07 & 3.85 \\
\hline $\mathrm{K}_{2} \mathrm{O}$ & 1.95 & 1.79 & 3.91 & 3.90 & 4.98 & 4.00 & 3.60 & 4.48 \\
\hline $\mathrm{P}_{2} \mathrm{O}_{5}$ & 0.26 & 0.22 & 0.11 & 0.12 & 0.02 & 0.04 & 0.03 & 0.03 \\
\hline LOI & 2.80 & 2.50 & 1.40 & 2.40 & 2.40 & 1.30 & 1.30 & 0.70 \\
\hline Total & 99.33 & 99.30 & 99.46 & 99.55 & 99.38 & 99.48 & 99.56 & 99.54 \\
\hline $\mathrm{Ba}$ & 867 & 967 & 1299 & 1133 & 1393 & 1001 & 958 & 1491 \\
\hline $\mathrm{Be}$ & 3 & 1 & 2 & 3 & 3 & 3 & 3 & 2 \\
\hline Co & 15.50 & 44.10 & 86.20 & 3.50 & 98.20 & 34.40 & 0.40 & 1.40 \\
\hline $\mathrm{Cs}$ & 3.40 & 3.80 & 2.20 & 2.10 & 3.90 & 1.90 & 3.40 & 1.30 \\
\hline $\mathrm{Ga}$ & 17.90 & 19.90 & 15.80 & 14.70 & 17.10 & 19.50 & 14.50 & 13.90 \\
\hline $\mathrm{Hf}$ & 3.60 & 4.10 & 6.40 & 6.00 & 7.10 & 8.20 & 7.20 & 5.60 \\
\hline $\mathrm{Nb}$ & 5.00 & 6.20 & 10.60 & 9.90 & 11.80 & 12.60 & 11.30 & 12.10 \\
\hline $\mathrm{Rb}$ & 53.30 & 57.90 & 114.20 & 131.00 & 169.30 & 175.20 & 152.00 & 140.80 \\
\hline $\mathrm{Sr}$ & 614.90 & 599.00 & 143.40 & 133.50 & 137.70 & 67.10 & 61.70 & 91.90 \\
\hline $\mathrm{Ta}$ & 0.30 & 0.40 & 0.90 & 0.60 & 1.00 & 1.00 & 1.10 & 0.80 \\
\hline Th & 5.60 & 5.50 & 11.50 & 10.50 & 13.10 & 14.50 & 13.50 & 12.60 \\
\hline $\mathrm{U}$ & 1.10 & 1.20 & 2.20 & 2.10 & 2.40 & 2.70 & 3.00 & 2.20 \\
\hline W & 1.10 & 145.70 & 447.20 & 0.80 & 537.50 & 191.60 & 1.10 & 0.60 \\
\hline $\mathrm{Zr}$ & 146.00 & 156.20 & 233.80 & 196.80 & 242.30 & 295.10 & 224.60 & 188.40 \\
\hline $\mathrm{Y}$ & 14.30 & 15.80 & 29.70 & 29.50 & 45.70 & 37.80 & 37.90 & 28.60 \\
\hline $\mathrm{Pb}$ & - & 2.40 & 15.60 & - & 16.10 & 17.30 & 11.90 & - \\
\hline $\mathrm{La}$ & 23.40 & 24.50 & 44.20 & 44.90 & 75.10 & 58.60 & 53.10 & 44.70 \\
\hline $\mathrm{Ce}$ & 47.20 & 51.50 & 92.30 & 83.70 & 105.90 & 78.50 & 112.00 & 90.80 \\
\hline $\operatorname{Pr}$ & 5.74 & 6.03 & 10.73 & 10.43 & 15.47 & 13.07 & 12.81 & 10.64 \\
\hline $\mathrm{Nd}$ & 23.8 & 23.70 & 41.60 & 40.90 & 60.50 & 51.50 & 47.30 & 42.80 \\
\hline $\mathrm{Sm}$ & 4.06 & 4.41 & 7.25 & 7.41 & 9.93 & 8.92 & 8.68 & 7.45 \\
\hline $\mathrm{Eu}$ & 1.23 & 1.26 & 1.67 & 1.67 & 2.04 & 1.89 & 1.72 & 1.53 \\
\hline $\mathrm{Gd}$ & 3.30 & 3.73 & 5.90 & 6.38 & 8.61 & 7.64 & 7.68 & 6.06 \\
\hline $\mathrm{Tb}$ & 0.55 & 0.55 & 0.89 & 0.96 & 1.27 & 1.18 & 1.07 & 0.96 \\
\hline Dy & 2.83 & 2.96 & 5.09 & 5.17 & 7.21 & 6.64 & 6.35 & 5.44 \\
\hline Ho & 0.53 & 0.56 & 1.00 & 1.14 & 1.45 & 1.26 & 1.13 & 1.06 \\
\hline Er & 1.49 & 1.65 & 2.95 & 2.97 & 4.14 & 3.69 & 3.68 & 3.04 \\
\hline $\mathrm{Tm}$ & 0.24 & 0.24 & 0.43 & 0.47 & 0.59 & 0.57 & 0.52 & 0.50 \\
\hline $\mathrm{Yb}$ & 1.50 & 1.47 & 2.88 & 3.02 & 3.71 & 3.61 & 3.25 & 3.15 \\
\hline $\mathrm{Lu}$ & 0.20 & 0.22 & 0.45 & 0.45 & 0.55 & 0.55 & 0.56 & 0.46 \\
\hline $\mathrm{Eu} / \mathrm{Eu}^{*}$ & 1.03 & 0.95 & 0.78 & 0.74 & 0.67 & 0.70 & 0.64 & 0.70 \\
\hline $\mathrm{La} / \mathrm{Yb}$ & 11.19 & 11.95 & 11.00 & 10.66 & 14.52 & 11.64 & 11.72 & 10.18 \\
\hline $\mathrm{Ga} / \mathrm{Al}$ & 1.95 & 2.15 & 2.13 & 2.09 & 2.29 & 2.50 & 2.09 & 2.09 \\
\hline
\end{tabular}


Ana Flávia Nunes Brittes et al.

Table 2. Continuation

\begin{tabular}{|c|c|c|c|c|c|c|c|c|}
\hline Samples & AB16 & AD12 & AD77 & AD37 & AD81 & AB06 & AD09(2) & AD43(1) \\
\hline Facies & 1 & 2 & 1 & 4 & 2 & 2 & 3 & 3 \\
\hline $\mathrm{SiO}_{2}$ & 75.24 & 75.56 & 75.57 & 75.65 & 75.67 & 75.70 & 75.70 & 75.98 \\
\hline $\mathrm{TiO}_{2}$ & 0.32 & 0.24 & 0.25 & 0.28 & 0.24 & 0.25 & 0.21 & 0.26 \\
\hline $\mathrm{Al}_{2} \mathrm{O}_{3}$ & 13.07 & 13.21 & 13.32 & 13.09 & 13.38 & 12.46 & 13.68 & 14.23 \\
\hline $\mathrm{Fe}_{2} \mathrm{O}_{3}$ & 2.70 & 1.12 & 1.13 & 1.22 & 1.25 & 1.81 & 1.09 & 1.56 \\
\hline $\mathrm{MnO}$ & 0.07 & 0.05 & 0.06 & 0.05 & 0.06 & 0.05 & 0.04 & 0.02 \\
\hline $\mathrm{MgO}$ & 0.33 & 0.25 & 0.16 & 0.12 & 0.27 & 0.22 & 0.35 & 0.41 \\
\hline $\mathrm{CaO}$ & 2.17 & 0.52 & 0.69 & 0.55 & 0.63 & 0.25 & 0.14 & 0.25 \\
\hline $\mathrm{Na}_{2} \mathrm{O}_{3}$ & 4.17 & 3.92 & 4.11 & 3.95 & 4.09 & 1.63 & 3.48 & 3.83 \\
\hline $\mathrm{K}_{2} \mathrm{O}$ & 1.59 & 4.44 & 4.42 & 4.71 & 4.12 & 7.43 & 5.03 & 3.34 \\
\hline $\mathrm{P}_{2} \mathrm{O}_{5}$ & 0.12 & 0.03 & 0.03 & 0.03 & 0.04 & 0.02 & 0.02 & 0.03 \\
\hline LOI & 1.00 & 0.80 & 1.00 & 0.40 & 1.30 & 0.80 & 1.60 & 1.50 \\
\hline Total & 99.60 & 99.53 & 99.53 & 99.40 & 99.56 & 99.60 & 99.55 & 99.69 \\
\hline $\mathrm{Ba}$ & 710 & 1346 & 1288 & 1575 & 1094 & 1105 & 1474 & 405 \\
\hline $\mathrm{Be}$ & $<1$ & 2 & 2 & 2 & 1 & $<1$ & 3 & 4 \\
\hline Co & 3.20 & 96.50 & 72.40 & 188.80 & 121.00 & $<0.20$ & 117.00 & 0.70 \\
\hline Cs & 2.10 & 0.80 & 1.90 & 1.40 & 1.50 & 2.10 & 3.60 & 1.80 \\
\hline $\mathrm{Ga}$ & 11.60 & 14.70 & 16.20 & 12.50 & 14.60 & 16.10 & 14.00 & 18.40 \\
\hline $\mathrm{Hf}$ & 4.20 & 5.30 & 6.00 & 7.50 & 5.50 & 6.70 & 6.50 & 6.00 \\
\hline $\mathrm{Nb}$ & 6.20 & 11.10 & 13.70 & 12.00 & 10.60 & 13.70 & 11.00 & 10.90 \\
\hline $\mathrm{Rb}$ & 52.90 & 143.80 & 147.60 & 130.10 & 120.80 & 195.40 & 158.00 & 134.60 \\
\hline $\mathrm{Sr}$ & 594.60 & 77.90 & 94.10 & 120.10 & 89.70 & 49.80 & 80.10 & 51.60 \\
\hline $\mathrm{Ta}$ & 0.50 & 1.00 & 1.00 & 1.30 & 1.00 & 1.10 & 1.20 & 0.80 \\
\hline Th & 6.20 & 13.00 & 13.50 & 12.90 & 11.50 & 17.50 & 13.00 & 12.90 \\
\hline $\mathrm{U}$ & 1.70 & 2.70 & 2.80 & 2.30 & 2.20 & 3.90 & 3.00 & 2.10 \\
\hline $\mathrm{W}$ & 0.80 & 564.60 & 373.50 & 979.40 & 686.20 & 1.20 & 637.40 & 1.60 \\
\hline $\mathrm{Zr}$ & 141.20 & 166.10 & 215.10 & 229.70 & 173.80 & 231.60 & 201.10 & 218.90 \\
\hline$Y$ & 10.70 & 32.60 & 33.40 & 33.20 & 30.90 & 49.10 & 31.60 & 25.50 \\
\hline $\mathrm{Pb}$ & - & 17.00 & 27.30 & 11.10 & 17.60 & 4.70 & 6.60 & - \\
\hline $\mathrm{La}$ & 30.30 & 40.90 & 49.70 & 50.40 & 42.80 & 49.80 & 61.40 & 41.30 \\
\hline $\mathrm{Ce}$ & 58.20 & 86.70 & 104.40 & 101.0 & 82.90 & 100.40 & 102.40 & 80.10 \\
\hline $\mathrm{Pr}$ & 6.42 & 10.22 & 11.73 & 12.12 & 10.31 & 11.96 & 14.55 & 9.16 \\
\hline $\mathrm{Nd}$ & 25.80 & 39.30 & 44.90 & 47.40 & 40.80 & 43.00 & 52.90 & 35.00 \\
\hline $\mathrm{Sm}$ & 3.77 & 7.19 & 8.01 & 8.17 & 7.16 & 9.07 & 8.56 & 5.82 \\
\hline $\mathrm{Eu}$ & 0.93 & 1.29 & 1.75 & 1.78 & 1.21 & 1.60 & 1.58 & 1.39 \\
\hline $\mathrm{Gd}$ & 2.89 & 5.97 & 6.75 & 6.72 & 5.85 & 8.29 & 5.90 & 4.38 \\
\hline $\mathrm{Tb}$ & 0.41 & 0.97 & 1.04 & 1.05 & 0.89 & 1.43 & 0.98 & 0.75 \\
\hline Dy & 2.24 & 5.45 & 5.81 & 5.75 & 4.92 & 8.86 & 5.36 & 4.36 \\
\hline Ho & 0.45 & 1.10 & 1.17 & 1.14 & 1.01 & 1.51 & 1.04 & 0.97 \\
\hline $\mathrm{Er}$ & 1.23 & 3.28 & 3.44 & 3.41 & 3.06 & 4.73 & 3.18 & 2.78 \\
\hline $\mathrm{Tm}$ & 0.18 & 0.49 & 0.51 & 0.49 & 0.45 & 0.69 & 0.49 & 0.42 \\
\hline $\mathrm{Yb}$ & 1.28 & 3.25 & 3.28 & 3.18 & 2.95 & 3.87 & 3.24 & 3.12 \\
\hline $\mathrm{Lu}$ & 0.19 & 0.49 & 0.50 & 0.49 & 0.47 & 0.67 & 0.50 & 0.42 \\
\hline $\mathrm{Eu} / \mathrm{Eu}^{*}$ & 0.86 & 0.60 & 0.72 & 0.73 & 0.57 & 0.56 & 0.67 & 0.84 \\
\hline $\mathrm{La} / \mathrm{Yb}$ & 16.98 & 9.02 & 10.87 & 11.37 & 10.41 & 9.23 & 13.59 & 9.50 \\
\hline $\mathrm{Ga} / \mathrm{Al}$ & 1.68 & 2.10 & 2.30 & 1.80 & 2.06 & 2.44 & 1.93 & 2.44 \\
\hline
\end{tabular}


Table 2. Continuation

\begin{tabular}{|c|c|c|c|c|c|c|c|c|}
\hline Samples & AB25 & AD9M & AD28 & AD43 & AD09(3) & AD10(10) & $\mathrm{AD2} / 2 \mathrm{~F}$ & AD09F \\
\hline Facies & 2 & 1 & 5 & 1 & 3 & 3 & Lithic Fragment & Lithic Fragment \\
\hline $\mathrm{SiO}_{2}$ & 76.20 & 76.25 & 76.32 & 76.59 & 76.70 & 77.11 & 78.23 & 78.31 \\
\hline $\mathrm{TiO}_{2}$ & 0.24 & 0.25 & 0.23 & 0.23 & 0.23 & 0.22 & 0.21 & 0.20 \\
\hline $\mathrm{Al}_{2} \mathrm{O}_{3}$ & 12.49 & 13.01 & 12.76 & 12.78 & 13.34 & 13.43 & 11.35 & 11.74 \\
\hline $\mathrm{Fe}_{2} \mathrm{O}_{3}$ & 2.02 & 1.93 & 1.66 & 1.38 & 1.61 & 1.40 & 1.37 & 1.66 \\
\hline $\mathrm{MnO}$ & 0.07 & 0.07 & 0.01 & 0.02 & 0.05 & 0.04 & 0.03 & 0.04 \\
\hline $\mathrm{MgO}$ & 0.29 & 0.37 & 0.05 & 0.11 & 0.42 & 0.26 & 0.03 & 0.23 \\
\hline $\mathrm{CaO}$ & 0.73 & 0.57 & 0.07 & 0.07 & 0.17 & 0.11 & 0.71 & 0.22 \\
\hline $\mathrm{Na}_{2} \mathrm{O}_{3}$ & 3.78 & 2.04 & 4.58 & 3.32 & 2.98 & 4.31 & 1.55 & 4.15 \\
\hline $\mathrm{K}_{2} \mathrm{O}$ & 3.94 & 5.31 & 4.19 & 5.33 & 4.25 & 2.94 & 6.26 & 3.30 \\
\hline $\mathrm{P}_{2} \mathrm{O}_{5}$ & 0.04 & 0.02 & $<0.01$ & 0.03 & 0.01 & 0.03 & 0.05 & $<0.01$ \\
\hline LOI & 1.40 & 1.20 & 0.70 & 0.50 & 1.70 & 1.50 & 0.40 & 0.70 \\
\hline Total & 99.61 & 99.60 & 99.64 & 99.66 & 99.54 & 99.68 & 99.62 & 99.66 \\
\hline $\mathrm{Ba}$ & 998 & 1455 & 739 & 844 & 1032 & 1074 & 2216 & 893 \\
\hline $\mathrm{Be}$ & $<1$ & 4 & 1 & 2 & 2 & 3 & 2 & 3 \\
\hline Co & 1.00 & 1.30 & 0.50 & 0.50 & 75.50 & 0.70 & 0.80 & 1.40 \\
\hline Cs & 1.50 & 3.40 & 0.70 & 1.60 & 3.80 & 1.50 & 3.20 & 2.10 \\
\hline $\mathrm{Ga}$ & 13.50 & 15.10 & 12.90 & 12.40 & 17.40 & 15.10 & 8.20 & 11.10 \\
\hline Hf & 4.70 & 7.20 & 6.80 & 7.10 & 6.10 & 7.70 & 4.90 & 4.40 \\
\hline $\mathrm{Nb}$ & 10.80 & 12.10 & 13.30 & 14.10 & 11.90 & 10.40 & 10.90 & 8.00 \\
\hline $\mathrm{Rb}$ & 113.10 & 173.60 & 109.40 & 143.50 & 176.50 & 118.10 & 164.60 & 110.40 \\
\hline $\mathrm{Sr}$ & 84.10 & 124.20 & 51.30 & 36.90 & 89.00 & 89.30 & 73.90 & 107.40 \\
\hline $\mathrm{Ta}$ & 0.80 & 1.10 & 1.00 & 1.00 & 1.00 & 0.70 & 0.80 & 0.50 \\
\hline Th & 11.50 & 13.00 & 14.40 & 13.70 & 14.30 & 11.40 & 11.10 & 9.90 \\
\hline $\mathrm{U}$ & 2.20 & 2.70 & 2.40 & 2.10 & 2.70 & 2.50 & 2.30 & 2.20 \\
\hline $\mathrm{W}$ & 0.80 & 1.60 & 0.90 & 1.40 & 381.40 & 0.80 & 2.00 & 0.70 \\
\hline $\mathrm{Zr}$ & 164.60 & 200.80 & 201.00 & 212.50 & 210.70 & 266.80 & 183.80 & 181.10 \\
\hline $\mathrm{Y}$ & 30.00 & 42.80 & 23.07 & 34.60 & 28.60 & 26.90 & 28.10 & 32.60 \\
\hline $\mathrm{Pb}$ & - & 23.40 & - & - & 10.10 & - & 9.60 & 5.60 \\
\hline $\mathrm{La}$ & 44.20 & 55.10 & 23.70 & 46.00 & 30.00 & 28.80 & 41.40 & 68.10 \\
\hline $\mathrm{Ce}$ & 79.60 & 93.80 & 36.60 & 61.20 & 80.00 & 66.70 & 82.30 & 69.80 \\
\hline $\operatorname{Pr}$ & 10.25 & 11.22 & 6.58 & 11.07 & 7.59 & 5.47 & 8.93 & 12.57 \\
\hline $\mathrm{Nd}$ & 39.10 & 41.80 & 23.80 & 42.50 & 27.30 & 20.50 & 35.20 & 43.40 \\
\hline $\mathrm{Sm}$ & 6.98 & 7.52 & 4.80 & 7.64 & 5.46 & 3.59 & 6.34 & 7.85 \\
\hline $\mathrm{Eu}$ & 1.45 & 1.55 & 0.87 & 1.43 & 1.06 & 0.94 & 1.29 & 1.35 \\
\hline $\mathrm{Gd}$ & 5.81 & 6.84 & 3.74 & 6.93 & 4.78 & 3.50 & 5.24 & 6.14 \\
\hline $\mathrm{Tb}$ & 0.93 & 1.05 & 0.66 & 1.11 & 0.85 & 0.74 & 0.81 & 0.90 \\
\hline Dy & 5.69 & 6.10 & 4.32 & 6.67 & 4.53 & 4.46 & 4.21 & 5.16 \\
\hline Ho & 1.00 & 1.33 & 0.94 & 1.30 & 0.96 & 0.99 & 0.84 & 1.10 \\
\hline $\mathrm{Er}$ & 3.23 & 3.63 & 2.68 & 3.85 & 3.09 & 2.90 & 2.38 & 3.29 \\
\hline $\mathrm{Tm}$ & 0.53 & 0.51 & 0.48 & 0.56 & 0.45 & 0.48 & 0.36 & 0.47 \\
\hline $\mathrm{Yb}$ & 3.32 & 3.23 & 3.38 & 3.55 & 2.97 & 3.41 & 2.17 & 2.69 \\
\hline $\mathrm{Lu}$ & 0.48 & 0.51 & 0.46 & 0.53 & 0.47 & 0.49 & 0.38 & 0.47 \\
\hline $\mathrm{Eu} / \mathrm{Eu}^{*}$ & 0.70 & 0.66 & 0.63 & 0.60 & 0.63 & 0.81 & 0.68 & 0.59 \\
\hline $\mathrm{La} / \mathrm{Yb}$ & 9.55 & 12.24 & 5.03 & 9.29 & 7.24 & 6.06 & 13.68 & 12.24 \\
\hline $\mathrm{Ga} / \mathrm{Al}$ & 2.04 & 2.19 & 1.91 & 1.83 & 2.46 & 2.12 & 1.37 & 1.79 \\
\hline
\end{tabular}




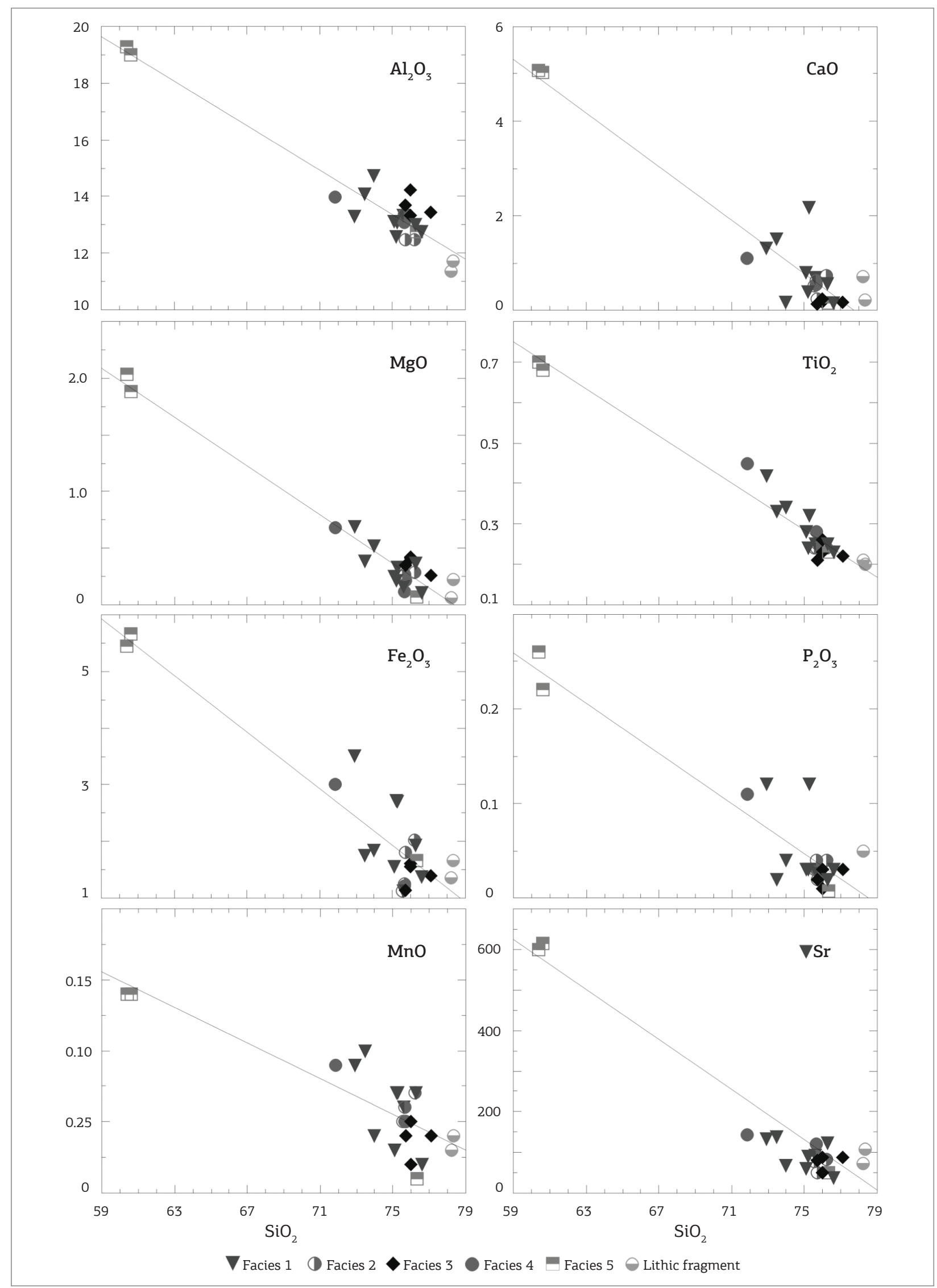

Figure 8. Harker Diagrams for the rocks of the Serra da Bocaina Formation (major and minor elements expressed in $\%$ oxides and trace elements in ppm, respectively). 


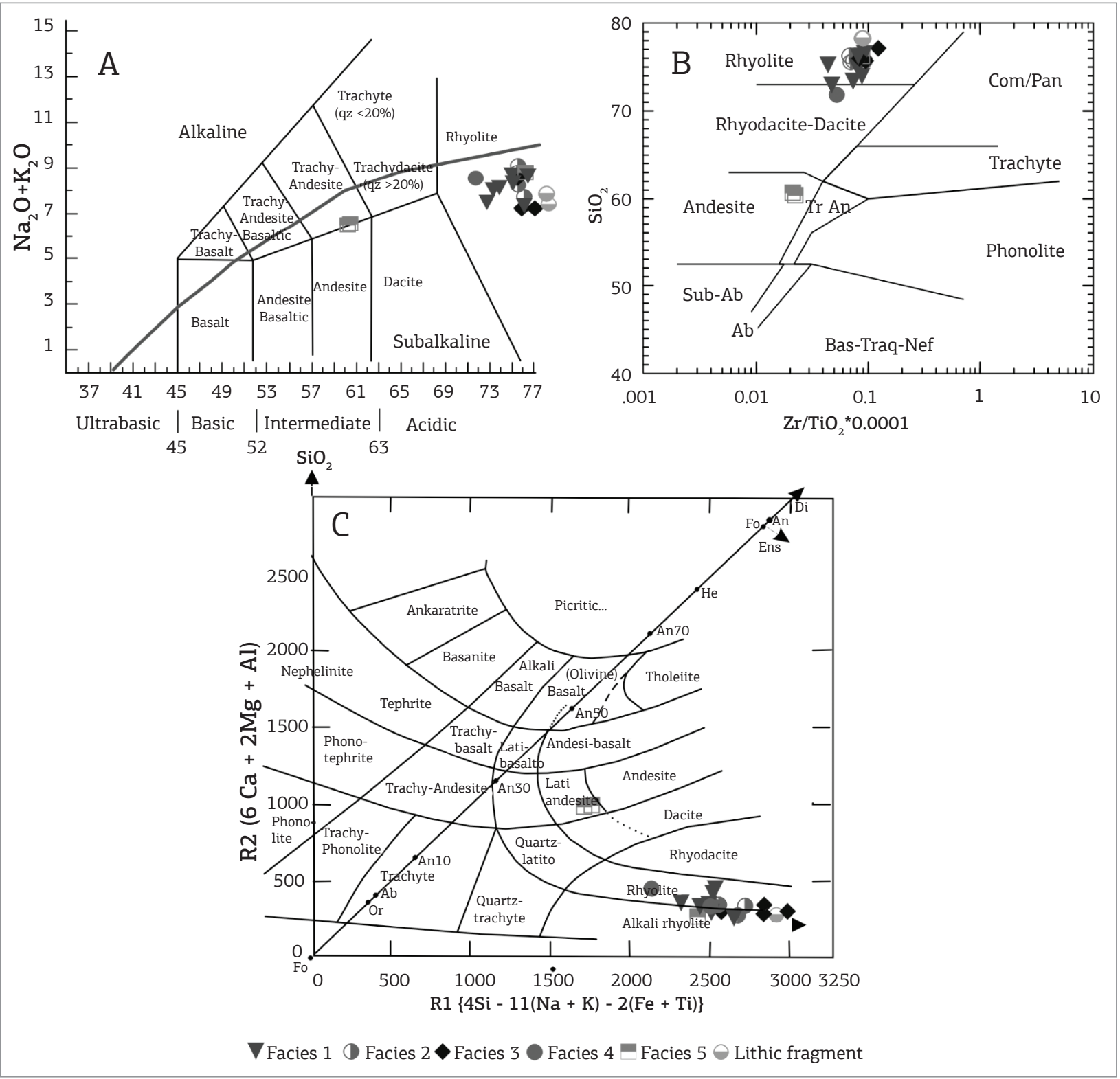

Figure 9. Classification of the Serra da Bocaina Formation rocks in the diagrams: (A) total alkalis versus silica (Le Bas 1986), with the boundary between the alkaline/subalkaline domain of Irvine \& Baragar (1971); (B) $\mathrm{SiO}_{2}$ versus $\mathrm{Zr} / \mathrm{TiO}_{2}$ (Winchester \& Floyd 1977); and (C) R1 versus R2 (De La Roche et al. 1980).

the pyroclastic rocks, but the layout of the points that represent them in Figs. 12A and B follows similar patterns $(\mathrm{La} / \mathrm{Yb}=11.19$ and 11.95, respectively; Tab. 2), which differ by the absence of $\mathrm{Eu}$ anomalies with $\mathrm{Eu} / \mathrm{Eu}^{*}$ ratios equal to 0.95 and 1.03 , respectively.

\section{GEOCHRONOLOGY}

The sample (AB35) of an ignimbrite belonging to the crystal-rich ignimbrite facies was selected for the geochronological study of the FSB.

\section{Methodology $\mathrm{Pb}-\mathrm{Pb}$ in zircon (evaporation)}

The sample was processed with conventional methods, such as crushing, grinding, sieving and concentration of the $0.090 \mathrm{~mm}$ fraction in the Laboratory of Sample Preparation and Laboratory of Chemical Dilution of the Department of Mineral Resources of the UFMT. After passing through the Frantz isodynamic magnetic separator, 150 grains of the least magnetic fractions were selected.

Two filaments facing each other were used in the applied method, as recommended by Kober $(1986,1987)$; one was an evaporation filament, which contained the zircon, and 


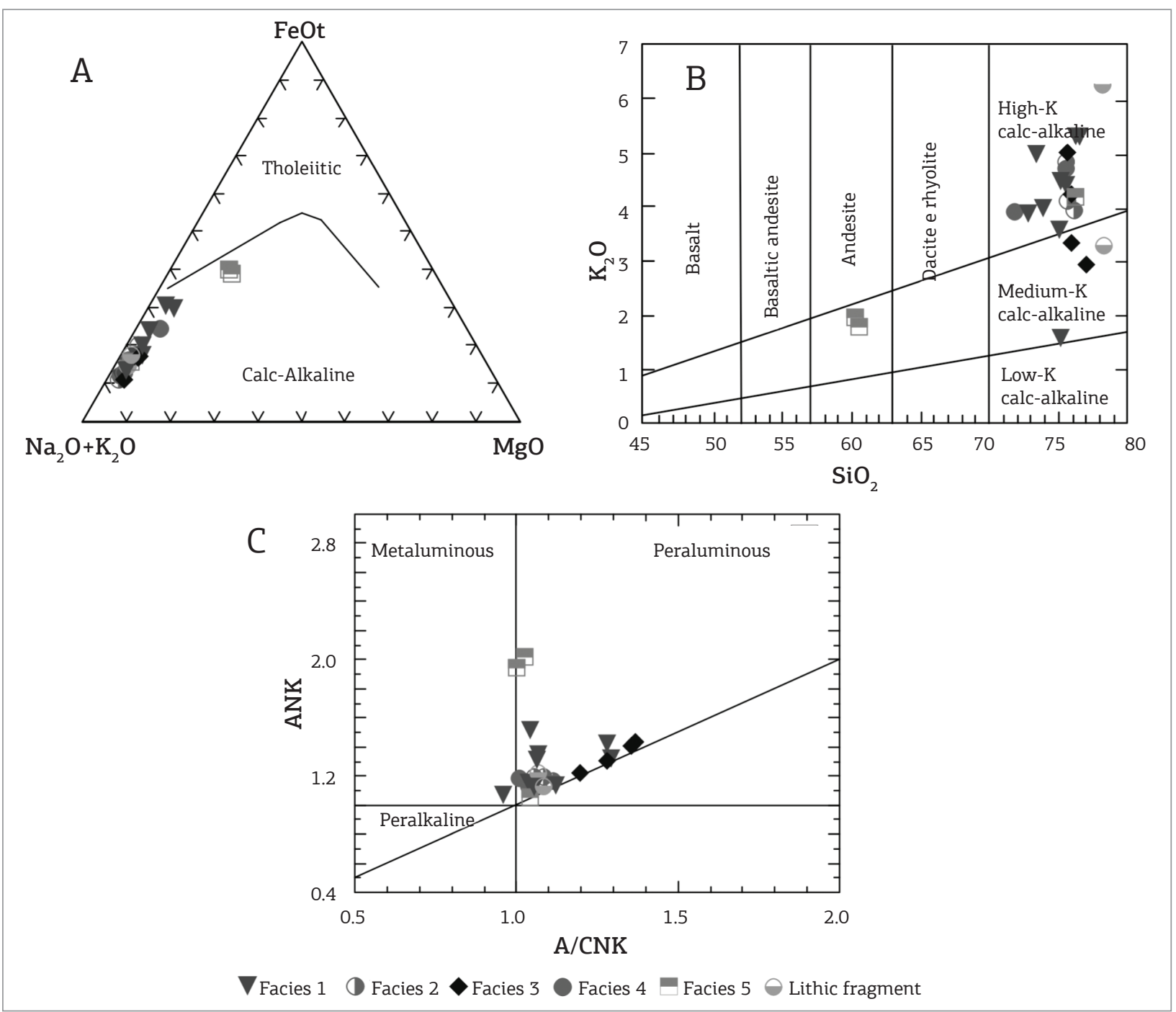

Figure 10. Distribution of the analyzed points of the Serra da Bocaina Formation in the diagrams: (A) AFM (Irvine \& Baragar 1971); (B) $\mathrm{K}_{2} \mathrm{O} \%$ versus $\mathrm{SiO}_{2} \%$ (Le Maitre 2002); and (C) A/CNK versus A/NK (Maniar \& Piccoli 1989).

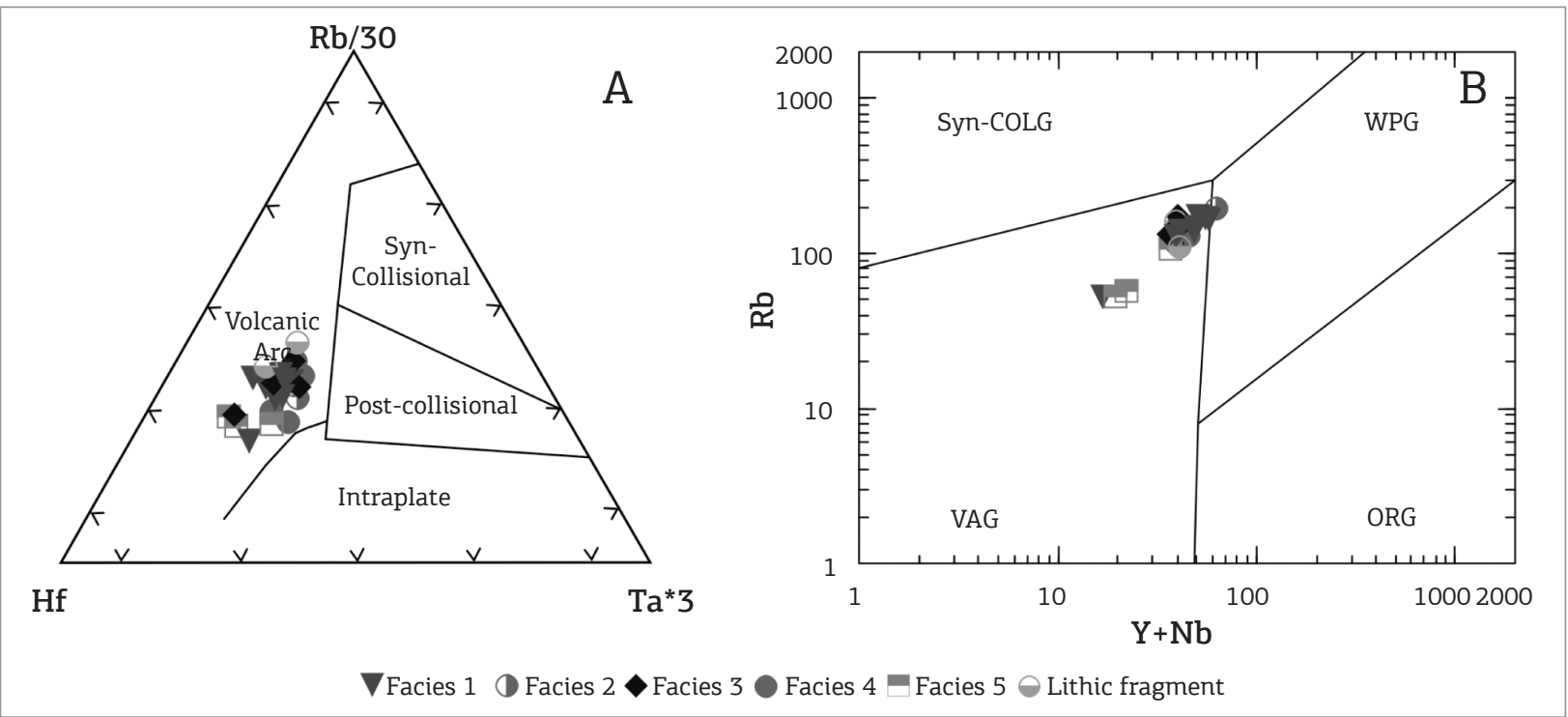

Figure 11. Distribution of the analyzed points of the Serra da Bocaina Formation in the diagrams: (A) Hf-Rb/30Ta*3 (Harris et al. 1986); and (B) Rb versus $\mathrm{Y}+\mathrm{Nb}$ (Pearce 1996). 


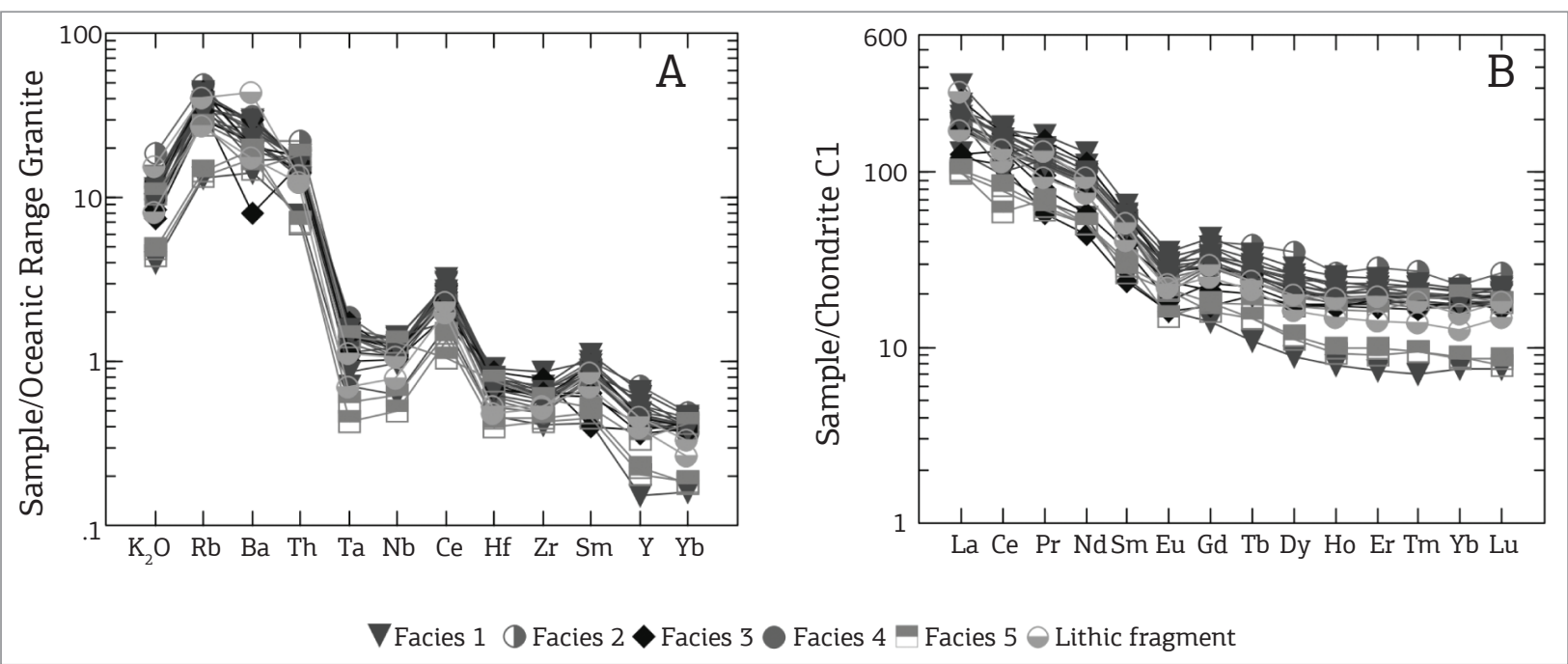

Figure 12. Distribution pattern of the representative points of the Serra da Bocaina Formation in the diagrams: (A) trace elements and $\mathrm{K}_{2} \mathrm{O}$, normalized by the values of the Meso-oceanic Range granites (Pearce et al. 1984); and (B) rare earth elements normalized by the Chondrite C1 values (Sun \& McDonough 1989).

the other was an ionization filament, from which the $\mathrm{Pb}$ is analyzed under different temperatures $(1,450,1,500$ and $\left.1,550^{\circ} \mathrm{C}\right)$. The $\mathrm{Pb}$ released from the zircon crystal lattice is immediately fixed to the ionization filament. During the heating of this filament (at approximately $1,050^{\circ} \mathrm{C}$ ), the emission intensities of the ${ }^{204} \mathrm{~Pb},{ }^{206} \mathrm{~Pb},{ }^{207} \mathrm{~Pb}$ and ${ }^{208} \mathrm{~Pb}$ isotopes are analyzed in the spectrometer. The presentation of results takes into consideration the deviations of sigma errors two of the ${ }^{207} \mathrm{~Pb} /{ }^{206} \mathrm{~Pb}$ ratios, and common $\mathrm{Pb}$ corrections are performed through the use of the two-stage $\mathrm{Pb}$ evolution model proposed by Stacey \& Kramers (1975) using the ${ }^{204} \mathrm{~Pb} /{ }^{206} \mathrm{~Pb}$ ratio. The data obtained are statistically treated in accordance with Gaudette et al. (1998).

\section{Results}

Of the 44 samples analyzed, 37 were eliminated because of high concentrations of common lead. The seven remaining samples showed good analytical results obtained during the second heating step (approximately $\left.1,500^{\circ} \mathrm{C}\right)$. For better analysis and results, only the 7 samples were used, which provided 144 isotope ratios (Tab. 5). The zircon crystals of the FSB are euhedral, subhedral and prismatic, with brown to whitish color that ranges from translucent to opaque, and at times these crystals exhibit moderate fracturing (Fig. 13).

The seven analyzed filaments $(\mathrm{AB} 35 \mathrm{R} / 6, \mathrm{AB} 35 \mathrm{R} / 20$, $\mathrm{AB} 35 \mathrm{R} / 26, \mathrm{AB} 35 \mathrm{R} / 28, \mathrm{AB} 35 \mathrm{R} / 30, \mathrm{AB} 35 / 38$ and $\mathrm{AB} 35 / 40$ ) exhibit ${ }^{207} \mathrm{~Pb} /{ }^{206} \mathrm{~Pb}$ age variation between $1,869.8$ and 1,881.8 Ma, with a mean age of 1,877.3 \pm 3.9 Ma (Mean square weighted deviation $-\mathrm{MSWD}=1.7$; Fig. 14). This result shows low common $\mathrm{Pb}$ ratios for the $\mathrm{AB} 35 \mathrm{R} / 6, \mathrm{AB} 35 \mathrm{R} / 26$ and $\mathrm{AB} 35 \mathrm{R} / 28$ samples with small corrections in the ${ }^{207} \mathrm{~Pb} / \mathrm{Pb}^{206}$ age and high common lead for the $A B 35 R / 20, A B 35 R / 30, A B 35 / 38$ and $A B 35 / 40$ samples, but they were included in the average age calculations presented because they provide similar ages as those with low common lead and acceptable analytical error.

The result obtained by the $\mathrm{Pb}-\mathrm{Pb}$ method of $1,877.3 \pm 3.9 \mathrm{Ma}$ is interpreted as the crystallization age of the crystal-rich ignimbrites and, consequently, of the explosive volcanism represented by the FSB.

\section{FINAL CONSIDERATIONS}

The Rio Apa Terrane is a small fragment of continental crust exposed in the region by the border of MS (Brazil) and Paraguay (Department of Concepcion). Covered to the south, west and north by sediments of the Pantanal Formation, it presents a contact of erosive and angular unconformity to the east with the rocks from the Paraguay Fold Belt.

Pyroclastic rocks were predominantly identified in the FSB, represented by the following four ignimbrite facies: ignimbrite breccia, crystal-rich ignimbrite, co-ignimbrite tuff and rheoignimbrite, and by one effusive facies.

Microscopically, these rocks are characterized by the presence of different pyroclastic products, such as lithic and pumice fragments, crystal clasts, pumices, fiammes, shards and crystallites of several dimensions and compositions, in addition to phenocrysts of quartz, plagioclase, and alkali feldspar immersed in a fine cineritic matrix. The alteration phases are represented by sericite, epidote/clinozoisite, calcite, clay minerals and chlorite, and the accessories by allanite, zircon, apatite and opaques, with high-temperature 
Ana Flávia Nunes Brittes et al.

Table 5. Lead isotope data from zircon multigrains of the sample AB35 from facies 2 of the Serra da Bocaina Formation

\begin{tabular}{|c|c|c|c|c|c|c|c|c|c|c|}
\hline Sample & $\mathrm{T}\left({ }^{\circ} \mathrm{C}\right)$ & Ratios & ${ }^{204} \mathrm{~Pb} /{ }^{206} \mathrm{~Pb}$ & $2 \sigma$ & $\left({ }^{208} \mathrm{~Pb} /{ }^{206} \mathrm{~Pb}\right) \mathrm{c}$ & $2 \sigma$ & $\left({ }^{207} \mathrm{~Pb} /{ }^{206} \mathrm{~Pb}\right) \mathrm{c}$ & $2 \sigma$ & Age (Ma) & $2 \sigma$ \\
\hline$A B 35 R / 6$ & 1,500 & $44 / 44$ & 0.000069 & 0.000003 & 0.46398 & 0.00174 & 0.11497 & 0.00037 & $1,879.7$ & 5.9 \\
\hline AB35R/20 & 1,500 & $30 / 38$ & 0.000986 & 0.000022 & 0.46697 & 0.0013 & 0.1151 & 0.00028 & $1,881.8$ & 4.4 \\
\hline AB35R/26 & 1,500 & $36 / 40$ & 0.000104 & 0.000006 & 0.36953 & 0.00098 & 0.11466 & 0.00037 & $1,874.8$ & 5.9 \\
\hline$A B 35 R / 28$ & 1,500 & $4 / 12$ & 0.000207 & 0.000014 & 0.37796 & 0.00327 & 0.11452 & 0.00035 & $1,872.7$ & 5.5 \\
\hline AB35R/30 & 1,500 & $8 / 58$ & 0.000501 & 0.000024 & 0.3756 & 0.00208 & 0.11476 & 0.00058 & $1,876.3$ & 9.1 \\
\hline AB35/38 & 1,500 & $8 / 8$ & 0.000763 & 0.000056 & 0.41445 & 0.00319 & 0.11434 & 0.00098 & $1,869.8$ & 15.4 \\
\hline \multirow[t]{2}{*}{$A B 35 / 40$} & 1,500 & $14 / 26$ & 0.000634 & 0.000169 & 0.35543 & 0.00728 & 0.11447 & 0.00073 & $1,871.8$ & 11.5 \\
\hline & & $144 / 226$ & & & & & \multicolumn{2}{|c|}{ Average age } & $1,877.3$ & 3.9 \\
\hline
\end{tabular}

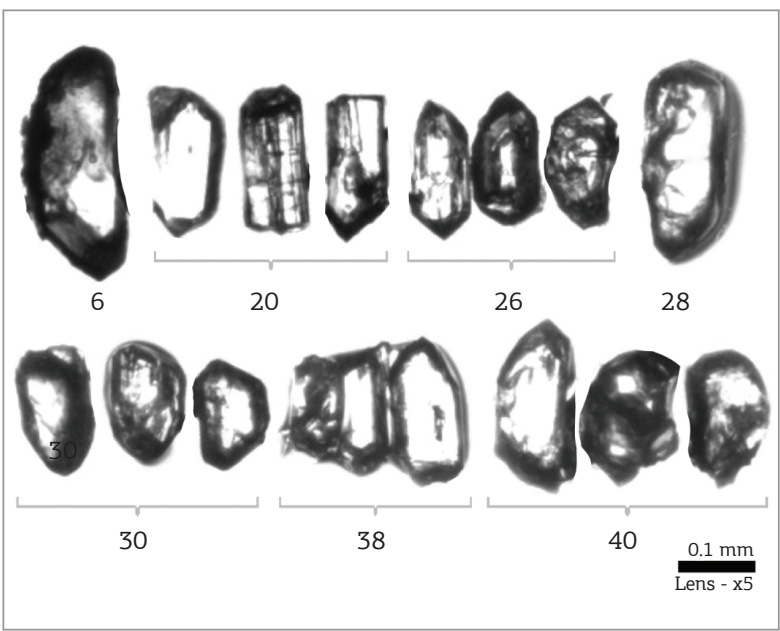

Figure 13. Photomicrograph of zircon crystals from the AB35 sample selected for dating.

biotite as the main mafic. The lithic fragments are composed of a felsic mesostasis, phenocrysts, biotite, opaques, glass and devitrification products, such as spherulite, axiolite, crystallites and graphic intergrowth. Facies 5 , which is effusive, is characterized by a porphyritic to glomeroporphyritic texture.

The primary structures of the FSB rocks are arranged homoclinally with bedding dip between $20^{\circ}$ and $50^{\circ} \mathrm{SE}$ and ESE and form an angle with the foliation $\left(\mathrm{S}_{1}\right)$. With respect to deformation, two stages were identified, one ductile $\left(\mathrm{F}_{1}\right)$ and one ductile-brittle $\left(\mathrm{F}_{2}\right)$. The oldest event, $\mathrm{F}_{1}$, is the most intense and dominant deformation; it is observed along the entire area studied in the pyroclastic and effusive rocks and is responsible for the development of the penetrative foliation $\left(S_{1}\right)$ and the shear zone. The $S_{1}$ foliation is represented by schistosity in the rocks of facies 1, 2, 4, 5 and by slaty cleavages in facies 3 with average attitude of 120/40. The Santa Rosa Shear Zone, which is related to the first deformation stage, $\mathrm{F}_{1}$, corresponds to the boundary between the rocks of facies 1 of the FSB and the Carandá Granite and indicates a reversetype movement, with top tectonic transportation moving

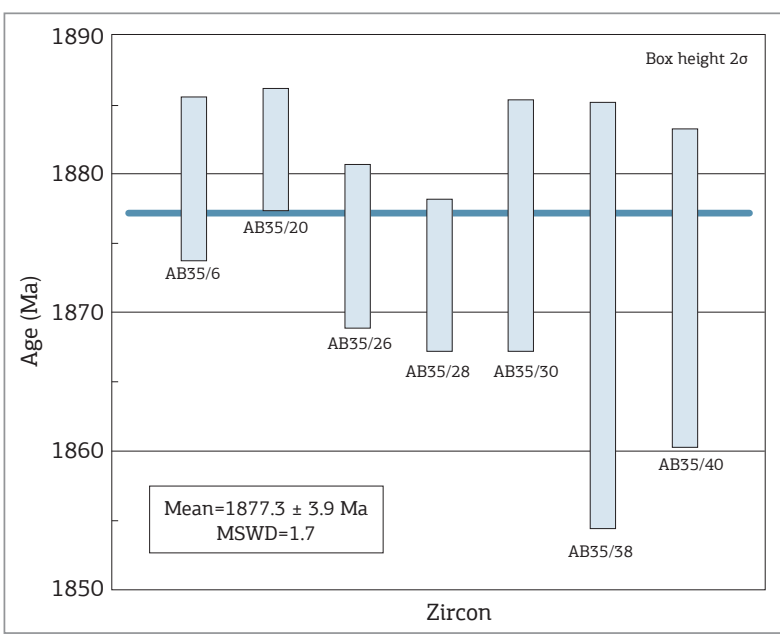

Figure 14. Diagram ages versus zircon crystals by Ludwig (2001) for the AB35 sample (crystal-rich ignimbrite facies).

NNW. The second deformation stage, $F_{2}$, appears with less deformation intensity and is marked by the generation of folds in the $S_{1}$ foliation. Foliation $S_{2}$ is represented by crenulation cleavage or by disjunctive cleavage with an average attitude of 220/90.

This volcanic-volcaniclastic set exhibits lowgrade metamorphism, which is coincident with the greenschist facies and characterized by the paragenesis albite + epidote + chlorite, and shows evidence of retro-metamorphism.

From the geochemical point of view, the FSB rocks are characterized as intermediate to predominantly acidic and classified as andesites and rhyolites; they are defined as medium to high-K calc-alkaline magmatism generated by fractionated crystallization in a continental magmatic arc environment. The REE concentrations show no anomalies to moderately negative $\mathrm{Eu}$ anomalies with $\mathrm{Eu} / \mathrm{Eu}^{*}$ ratios between 0.56 and 1.03. In the effusive rocks, which are hydrothermally altered, trace element values are always lower than those of the pyroclastic rocks but with no Eu anomaly.

Considering the subdivision and tectonic evolution of the Rio Apa Terrane, the studied rocks portray an extrusive 
magmatic event, which was dominantly explosive and related to the evolution of the Amoguijá Magmatic Arc; this event is Orosirian in age at $1877.3 \pm 3.9 \mathrm{Ma}$, according to $\mathrm{Pb}-\mathrm{Pb}$ zircon testing results.

Considering the deformation and metamorphic pattern observed in the studied rocks, we suggest that the FSB rocks were tectonically transported from the ESE to the WNW in a convergent tectonic regime that was dominated by frontal slopes of low-to-medium dipping and compatible with the greenschist facies metamorphism at a crustal level.

Ar-Ar and K-Ar data of approximately $1.3 \mathrm{Ga}$, which has been presented for the plutonic and volcanic rocks of the Amoguijá Magmatic Arc (Cordani et al. 2010), suggest that the studied effusive and pyroclastic rocks were deformed and metamorphosed during the San Ignácio Orogeny ( 1.4 to $1.3 \mathrm{Ga}$ ), which is observed in the Paraguá Terrane in the SW of the Amazonian Craton.

\section{ACKNOWLEDGEMENTS}

The authors thank the Brazilian National Agency for the Support and Evaluation of Graduate Education (Coordenação de Aperfeiçoamento de Pessoal de Nível Superior - CAPES)/National Program of Academic Cooperation (Programa Nacional de Cooperação Acadêmica PROCAD) (096/2007), Mato Grosso State Research Support Foundation (Fundação de Amparo à Pesquisa do Estado do Mato Grosso - FAPEMAT) (Process \#448287/2009) and CAPES/National Institute of Sciences and Geoscience Technology of the Amazon (Instituto Nacional de Ciências e Tecnologia de Geociências da Amazônia - GEOCIAM) for the funding of geochronological/chemical analyses and a masters program scholarship for the first author. The authors also thank the Graduate Program in Geosciences of the UFMT and the Crustal and Tectonic Evolution Research Group (Guaporé) for the financial and logistical support.

\section{REFERENCES}

Almeida F.F.M. 1964. Geologia do centro-oeste mato-grossense [Geology of central-western Mato Grosso state]. Rio de Janeiro, DNPM/DGM, Boletim 215, p. 137.

Almeida F.F.M. 1978. Tectonic map of South America 1:5.000.000. Explanatory note, Brasília DNPM/DGMW/UNESCO, p. 23.

Amaral G. 1974. Geologia Pré Cambriana da Região Amazônica [Precambrian Geology of the Amazon region]. Tese de Doutorado [Ph.D. Dissertation]. Instituto de Geociências, Universidade de São Paulo, São Paulo, p. 212.

Amaral G. 1984. Províncias Tapajós e Rio Branco [Tapajós and Rio Branco Provinces]. In: Almeida F.F.M \& Hasui Y (eds.). O Précambriano do Brasil [Precambrian in Brazill. São Paulo, Edgard Blücher, p. 6-35.

Araújo H.J.T., Santos Neto A., Trindade C.A.H., Pinto J.C.A., Montalvão R.M.G., Dourado T.D.C.; Palmeira R.C.B., Tassinari C.C.G. 1982. Projeto RADAMBRASIL. Levantamento de Recursos Naturais, Vol. 28. Folha SF. 21 - Campo Grande. Rio de Janeiro, Ministério das Minas e EnergiaSecretaria Geral, escala 1: 1.000.000 [RADAMBRASIL Project. Survey of Natural Resources, Vol. 28, Sheet SF. 21 - Campo Grande. Rio de Janeiro, Ministry of Mines and Energy, General Department, scale 1:1,000,000]. Available at: http://library.wur.nl/isric/index2.html?url=http://ibrary. wur.nl/WebQuery/isric/6773. Accessed: Dec/19/2012.

Barrett T.J. \& MacLean W.H. 1999. Volcanic sequences, lithogeochemistry, and hydrothermal alteration in some bimodal volcanic-associated massive sulfide systems. In: Barrie C.T \& Hannington M.D. (eds.). Volcanic-associated massive sulfide systems: processes and examples in modern and ancient settings. Reviews in Economic Geology, 8:101-131.

Brittes A.F.N. \& Plens D.P. 2010. Caracterização geológica da Serra da Bocaina, com ênfase na Formação Serra da Bocaina - Terreno Rio Apa - Sul do Craton Amazônico - Porto Murtinho - MS [Geological characterization of the Serra da Bocaina, with emphasis on the Serra da Bocaina Formation - Rio Apa Terrane - south of the Amazonian
Craton - Porto Murtinho - MS]. Trabalho de Conclusão de Curso [Undergraduate thesis]. Instituto de Ciências Exatas e da Terra, Universidade Federal de Mato Grosso, Cuiabá, p. 20-50.

Brittes A.F.N., Plens D.P., Ruiz A.S., Sousa M.Z.A., Batata M.E.F. 2010. Caracterização geológica e petrográfica da Formação Serra da Bocaina - Terreno Rio Apa - Sul do Cráton Amazônico - Porto Murtinho - MS [Geological and petrographic characterization of the Serra da Bocaina Formation - Rio Apa Terrane - South of the Amazonian Craton - Porto Murinho - MS]. In: 45 Congresso Brasileiro de Geologia, CD-ROM.

Brittes A.F.N., Plens D.P., Ruiz A.S., Sousa M.Z.A., Batata M.E.F. 2011 a. Caracterização estrutural e metamórfica da Formação Serra da Bocaina e do Granito Carandá - Terreno Rio Apa - Sul do Cráton Amazônico - Porto Murtinho (MS) [Structural and metamorphic characterization of the Serra da Bocaina Formation and Carandá Granite - Rio Apa Terrane -South of the Amazonian Craton - Porto Murtinho (MS)]. In: XIII Simp. Nac. de Estudos Tectônicos, 1, p. 33-36.

Brittes A.F.N., Sousa M.Z.A., Ruiz A.S., Batata M.E.F., Plens D.P. 2011b. Petrografia e geoquímica da Formação Serra da Bocaina Terreno Rio Apa - Sul do Cráton Amazônico - Porto Murtinho - MS [Petrography and geochemistry of the Serra da Bocaina Formation Rio Apa Terrane - South of the Amazonian Craton - Porto Murtinho - MS]. In: V Simp. Vulcanismo e Ambientes Associados, CD-ROM .

Brittes A.F.N., Sousa M.Z.A., Ruiz A.S., Batata M.E.F., Plens D.P. 2011c. Petrografia, estrutural e geoquímica da Formação Serra da Bocaina do Arco Magmático Amonguijá - Terreno Rio Apa (MS) [Petrography, structure and geochemistry of the Serra da Bocaina Formation of the Amonguijá Magmatic Arc - Rio Apa Terrane (MS)]. In: 12 Simpósio de Geologia da Amazônia, CD-ROM.

Cordani U.G., Tassinari C.C.G., Teixeira W., Basei M.A.S., Kawasita K. 1979. Evolução tectônica da Amazônia com base nos dados geocronológicos [Tectonic evolution of the Amazon based on geochronological data]. In: Congresso Geológico Chileno, 2, Chile. Atas, p. 137-48. 
Cordani U.G, Tassinari C.C.G., Rolim D.R. 2005. The basement of the Rio Apa Craton in Mato Grosso do Sul (Brazil) and northern Paraguay: a geochronological correlation with the tectonic provinces of the south-western Amazonian Craton. In: Gondwana 12, Abstract, p. 112. Available at: http://www.geologiadelparaguay. com/Reconocimento-Geocronol\%C3\%B3gico-do-Crat\%C3\%B3ndo-R\%C3\%ADo-Apa.PDF. Accessed on: 19/12/2012.

Cordani U.G., Teixeira W., Tassinari C.C.G., Ruiz A.S. 2010, The Rio Apa Craton in Mato Grosso do Sul (Brazil) and Northern Paraguay: geochronological evolution, correlations and tectonic implications for Rodinia and Gondwana. American Journal of Science, 310(9):981-1023.

De La Roche H., Leterrier J., GrandClaude P., Marchal M. 1980. A classification of volcanic and plutonic rocks using $R_{1} R_{2}$-diagram and major-element analyses - its relationships with current nomenclature. Chemical Geology, 29(1-4):183-210.

Gaudette H.E., Lafon J.M., Macambira M.J.B., Moura C.A.V., Scheller T., 1998. Comparison of single filament $\mathrm{Pb}$ evaporation/ionization zircon ages with conventional U-Pb results: examples from the Precambrian of Brazil. Journal of South American Earth Sciences, 11(4), 351-363.

Godoi H.O., Martins E.G., Mello C.R., Scislewski G. 2001. Geologia. MME/SG. Projeto Radam - Brasil. Programa Levantamentos Geológicos Básicos do Brasil. Folhas Corumbá (SE. 21-Y-D), Aldeia Tomázia, (SF. 21-V-B) e Porto Murtinho (SF. 21-V-D), Mato Grosso do Sul, escala 1: 250.000 [Radam Project - Brazil. Program of Basic Geological Surveys of Brazil. Corumbá (SE. 21-Y-D), Aldeia Tomázia, (SF. 21-V-B) and Porto Murtinho (SF. 21-V-D) Reports, Mato Grosso do sul, scale 1:250,000].

Godoy A.M, Manzano J.C, Araújo L.M.B, Silva J.A. 2010. Suíte Vulcânica Serra da Bocaina, Grupo Amoguijá, Maciço Rio Apa - MS [Serra da Bocaina Volcanic Suite, Amoguijá Group, Rio Apa Massif MS]. Geociências, 29(4):571-587.

Harris N.B.W., Pearce J.A., Tindle A.G. 1986. Geochemical characteristics of collision-zone magmatism. Geological Society, London, Special Publications, 19:67-81.

Hasui Y. \& Almeida F.F.M. 1970. Geocronologia do centro-oeste brasileiro [Geochronology of central-western Brazill. São Paulo. Sociedade Brasileira de Geologia, Boletim 19, p. 1-26.

Irvine I.N. \& Baragar W.R.A. 1971. A guide to the chemical classification of the common volcanics rocks. Canadian Journal Earth Science, 8(5):523-548.

Kober B. 1986. Whole-grain evaporation for ${ }^{207} \mathrm{~Pb} /{ }^{206} \mathrm{~Pb}$-ageinvestigations on single zircons using a double-filament thermal ion source. Contributions to Mineralogy and Petrology, 93(4):482-490.

Kober B. 1987. Single-zircon evaporation combined with $\mathrm{Pb}^{+}$emitter bedding for ${ }^{207} \mathrm{~Pb} / 206 \mathrm{~Pb}$-age investigations using thermal ion mass spectrometry, and implications to zirconology. Contributions to Mineralogy and Petrology, 96(1):63-71.

Lacerda Filho J.W., Brito R.S.C., Silva M.G., Oliveira C.C., Moreton L.C., Martins E.G., Lopes R.C., Lima T.M., Larizzatti J.H., Valente C.R. 2006. Geologia e recursos minerais do estado de Mato Grosso do Sul [Geology and mineral resources of the state of Mato Grosso do Sul]. Programa Integração, Atualização e Difusão de Dados de Geologia do Brasil. Convênio CPRM/SICME - MS, MME, p. 10-28.

Le Bas M.J., Le Maitre R.W., Streckeisen A., Zanettin B.A. 1986. Chemical classification of volcanic rocks based on total alkali-silica diagram. Journal of Petrology, 27(3):745-750.

Le Maitre R.W. 2002. Igneous rocks: a classification and glossary of terms: recommendations of the International Union of Geological Sciences Subcommission on the Systematics of Igneous Rocks. Cambridge, Cambridge University Press, p. 236.
Litherland M. \& Bloomfield K. 1981. The proterozoic history of eastern Bolivia. Precambrian Research, 15(2):157-179.

Litherland M., Annells R.N., Appleton J.D., Berrangé J.P., Bloomfield K., Burton C.C.J., Darbyshire D.P.F., Fletcher C.J.N., Hawkins M.P., Klinck B.A., Llanos A., Mithcell W.I., O'Connor E.A., Pitfield P.E.J., Power G.E, Webb B.C. (eds.) 1986. The geology and mineral resources of the Bolivian Precambrian shield. London, Her Majesty's Stationery Office, p. 140.

Ludwig K.R., 2001. A Geochronological Toolkit for Microsoft Excel. Berkeley Geochronological Center, Special Publication 1A, p. 59.

Maniar P.D. \& Piccoli P.M. 1989. Tectonic discrimination of granitoids. Geological Society of American Bulletin, 101(5):635-643.

Petri, S., Coimbra, A.M., Amaral, G., Ojeda, H.O., Fúlfaro, V.J. Ponçano, V.L. 1986. Código brasileiro de nomenclatura estratigráfica [Brazilian code of stratigraphic nomenclature]. Revista Brasileira de Geociências, 16(4):370-415.

Pearce J.A., Harris N.B.W., Tindle A.G. 1984. Trace element discrimination diagrams for the tectonic interpretation of granitic rocks. Journal of Petrology, 25(4):956-983.

Pearce J.A. 1996. Sources and settings of granitic rocks. Episodes, 19(4):120-125.

Ramos V. A. \& Vujovich G.I. 1993. The Pampia craton within western Gondwanaland. In Ortega-Gutiérrez, F., Coney-García E., GómezCaballero, A. (Eds.) Proceedings of The First Circum-Pacific and Circum-Atlantic Terrane Conference, Mexico, 113-116.

Ramos V.A. 2008. The Basement of the Central Andes: the Arequipa and related terranes. Annual Review of Earth and Planetary Sciences, 36:289-324

Ruiz A.S. 2005. Evolução geológica do Sudoeste do Cráton Amazônico região limítrofe Brasil-Bolívia - Mato Grosso. Tese de Doutorado, Instituto de Geociências e Ciências Exatas, Universidade Estadual Paulista [Geological evolution of southwestern Amazonian Craton, Brazil-Bolivia border region - Mato Grosso. Ph.D. Dissertation, Institute of Geosciences and Exact Sciences, State University of São Paulo], Rio Claro, p. 14-245.

Ruiz A.S., Simões L.S.A., Brito Neves B.B. 2005. Maciço Rio Apa: extremo meridional do Cráton Amazônico [Rio Apa Massif: southernmost Amazonian Craton]. In: SBG: Simp. Estudos Tectônicos, 10, Curitiba, Anais, p. 301-304

Ruiz A.S., Matos J.B., Sousa M.Z.A., Lima G.A., Batata M.E.F. 2010. Mapeamento Geológico e Levantamento de Recursos Minerais da Folha Santa Bárbara (SD.21-Y-C-V). Cuiabá, CPRM/UFMT, Relatório Etapa de Mobilização [Geological Mapping and Mineral Resources Survey of the Santa Bárbara Report (SD.21-Y-C-V). Cuiabá, CPRM/ UFMT, Mobilization Step Report], p. 35.

Stacey J.S., Kramers J.D. 1975. Approximation of terrestrial lead isotopic evolution by a two-stage model. Earth and Planetary Sciences Letters, 26(2):207-221.

Sun S.S. \& McDonough W.F. 1989. Chemical and isotopic systematics of oceanic basalts: implications for mantle composition and process. Geological Society, London, Special Publication, 42:313-345.

Suszczynski E.F. 1970. La geologie et La tectonique de la plateforme Amazonienne. Geologische Rundschau, 59(3):1232-1253.

Winchester J.A. \& Floyd P.A. 1977. Geochemical discrimination of different magma series and their differentiation products using immobile elements. Chemical Geology, 20:325-343.

Arquivo digital disponível on-line no site www.sbgeo.org.br 